\title{
EL ENANO EN LA PLASTICA MAYA
}

\section{Por Marta Foncerrada de Molina}

Es notable la variedad de tipos humanos que se encuentran representados en la plástica maya. Aparecen personajes con diversos rasgos físicos y varia complexión, hombres jóvenes, maduros, viejos y con menos frecuencia niños, así como también imágenes de mujeres identificadas como tales, en general, por la interpretación que los epigrafistas hacen de ciertos jeroglificos asociados a las figuras 1 y por formas en el atavio como es, por ejemplo, la falda larga, aun cuando éste no es un elemento diagnóstico que las distinga infaliblemente de las del sexo masculino.

El tema de las presentes consideraciones es reflexionar sobre la inclusión en este inventario de imágenes de un tipo físico aberrante: el enano. Me limitaré a discutir su presencia en la escultura monumental, en la pintura mural y en relieves en placas de jade pertenecientes al clásico tardío maya, a sabiendas de que el enano aparece también en pequeñas esculturas de barro y en la cerámica policroma. La discusión del motivo iconográfico en estas dos últimas expresiones plásticas la dejo para un futuro trabajo. Considero, sin embargo, de interés presentar en esta disertación una lista que incluye las representaciones más importantes de enanos en todas las manifestaciones artisticas antes mencionadas.

La primera reflexión en torno a las imágenes de enanos en el arte maya es la de despejar la duda que suscita la diminuta figura en relación a la posibilidad de confundirla con la de un niño. El muestrario de niños, como dije ya anteriormente, no es muy abundante en el arte maya; sin embargo, respecto a los monumentos en los que aparecen como son algunos de Piedras Negras, de Palenque, y el pequeño ser humano pintado en el muro trasero del cuarto 1 de Bonampak, puede argüirse que son imágenes que muestran rasgos físicos y proporciones normales que difieren básicamente de las del enano.

En el caso de Piedras Negras, la presencia en sus monumentos de mujeres y de niños, significa para Tatiana Proskouriakoff en su revelador artículo sobre el contenido histórico de los monumentos del sitio, que la conjugación de estas dos imágenes implica el expreso registro representativo que el artista hizo de rèlaciones dinásticas y de linaje en

1 Proskouriakoff, 1964, pp. 81 a 99. 
la ciudad. Argumentación que está basada y se complementa con el acucioso análisis y la relación que la investigadora hizo entre las fechas calendáricas y los glifos no calendáricos contenidos en las inscripciones de dichos monumentos. Cito a continuación a la autora: "El énfasis en el tema familiar [presencia de mujeres y niños] si aceptado como histórico, nos lleva inevitablemente a asuntos de genealogía y a la adquisición de un status preeminente." 2

En Bonampak me parece que pueden hacerse observaciones semejantes a las de Piedras Negras. En la escena del cuarto 1, un sirviente sostiene en brazos a un niño, acontecimiento que Kubler ${ }^{3}$ ha denominado "la presentación del niño" ya que al pequeño se le introduce a un recinto en el que están reunidos un grupo de dignatarios ricamente ataviados. Este niño cuya imagen se repite sentado en el regazo de una mujer en el cuarto 3 parece, por el ambiente solemne al que se asoma, poseer, por derecho, una especial dignidad jerárquica posiblemente relacionada con su específica legitimidad de rango dinástico como ocurre en Piedras Negras.

Semejante a lo arriba expuesto para Piedras Negras y Bonampak parece ser el caso de Palenque, en donde se representó a un niño que carga en los brazos un adulto en cada uno de los cuatro pilares de la fachada norte del Templo de las Inscripciones. El carácter estrictamente humano de los infantes en cuanto a sus proporciones y apariencia física se desvirtúa por la prolongación serpentina de uno de sus pies lo que, a mi juicio, no invalida ni su identificación como ser humano de tierna edad ni tamoco su significación histórica en la vida de la ciudad. El elemento serpentino señala seguramente un status divino a la vez que humano como con tanta frecuencia ocurre utilizando diversos símbolos, en la iconografía de muchas otras culturas.

A la luz de los ejemplos anteriores puede decirse que, a pesar de la corta estatura del niño y del enano, el niño fue manejado por los artistas con recursos de expresión naturalista y de estilización figurativa similares a los utilizados para las imágenes de adultos. Estos elementos formales definitivamente producen un tipo de imagen distinta a la de seres de cabeza grande, brazos y piernas cortas, tendencia a la obesidad, características físicas que nos permiten identificar con certeza la presencia del enano en el arte maya. Estas reflexiones pudiesen parecer demasiado obvias. Sin embargo, consideré de interés dejarlas apuntadas

2 Proskouriakoff, 1960, p. 464.

3 Kubler, 1969, p. 9. 


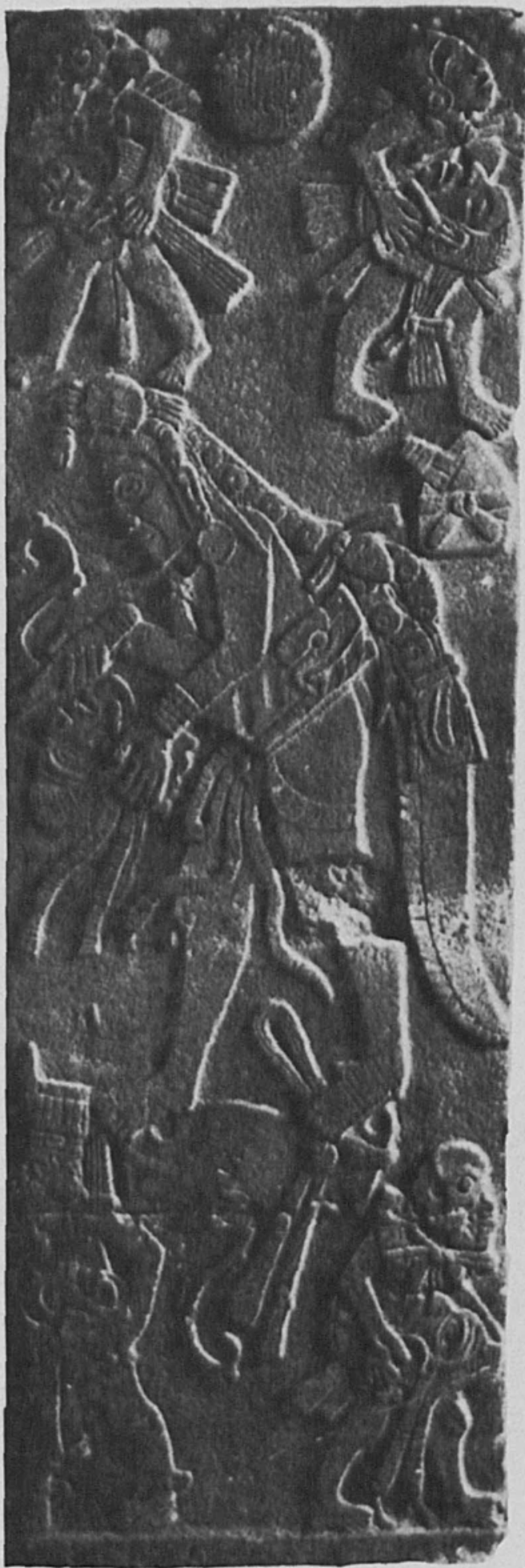

Figura 1. Bilbao. Estela 1 (Parsons, 1969, lámina 34a).

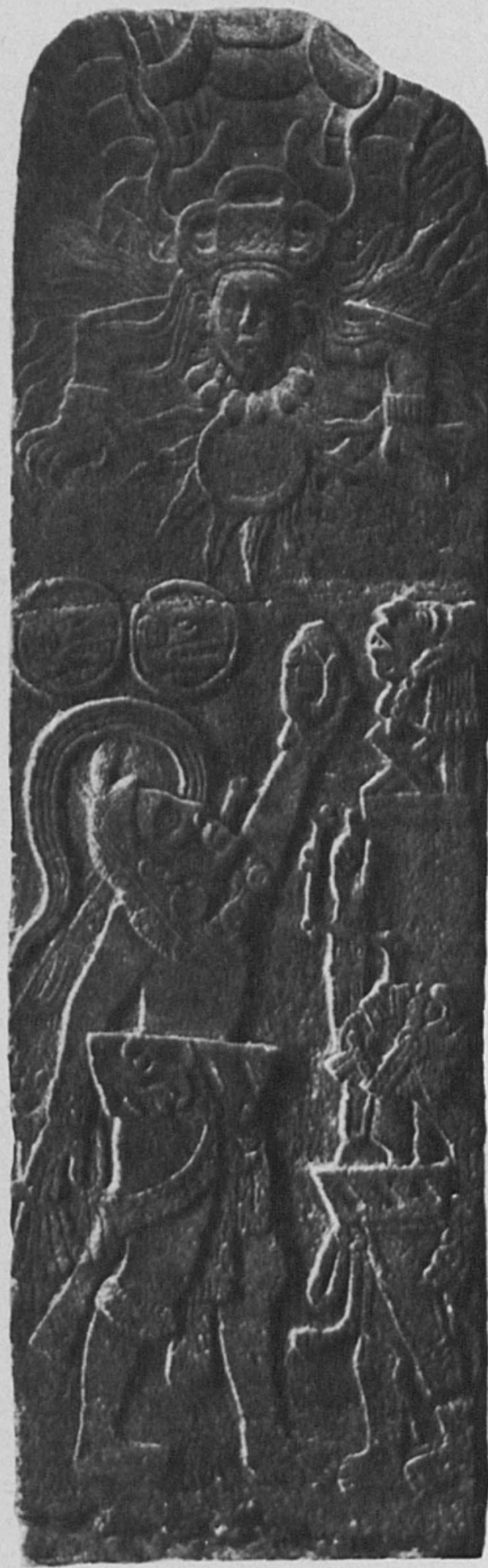

Figura 2. Bilbao. Estela 3 (Parsons, 1969, lámina 32a). 


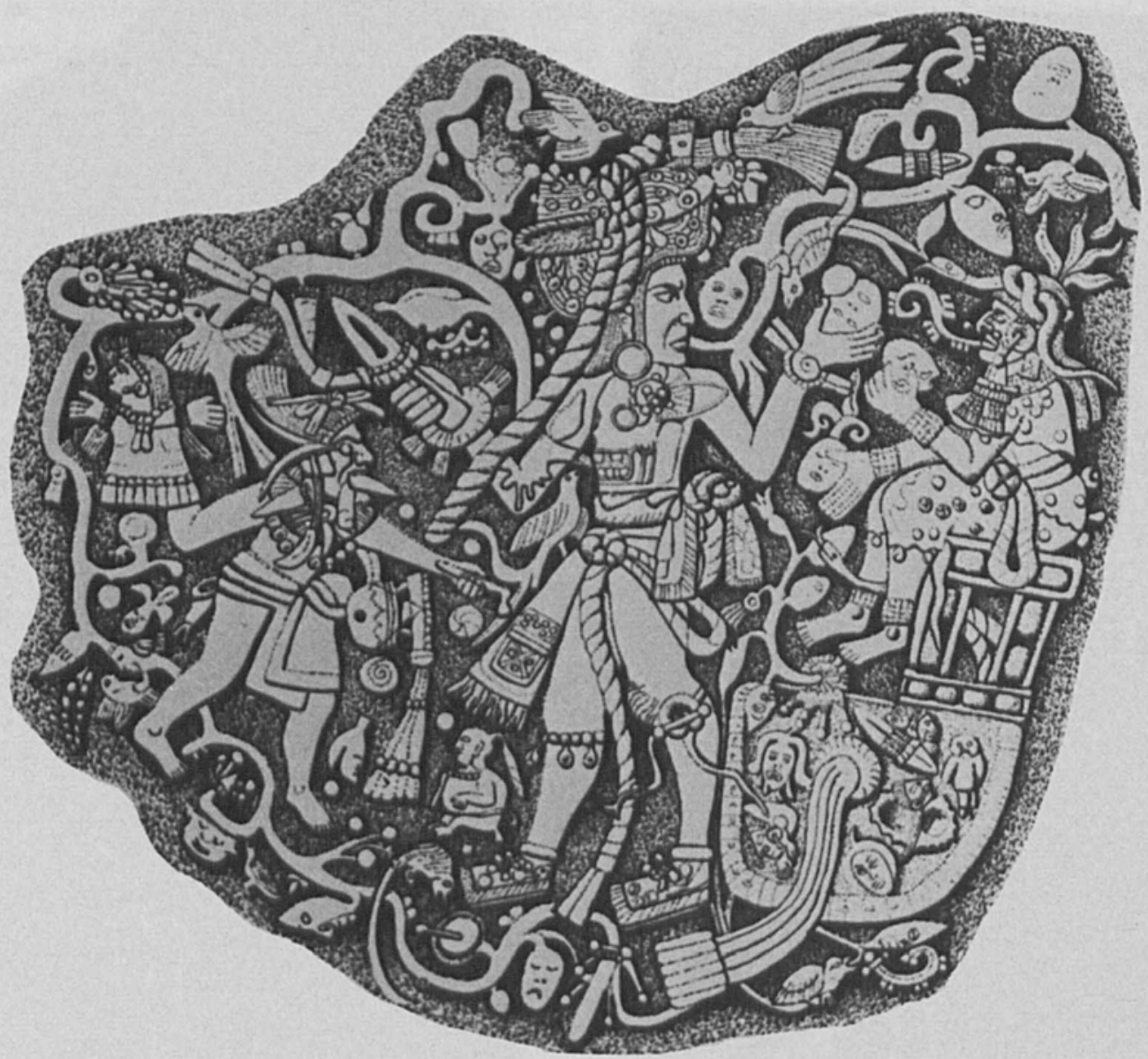

Figura 3. Bilbao. Monumento 21 (Parsons, 1969. Frontispicio, volúmen II).
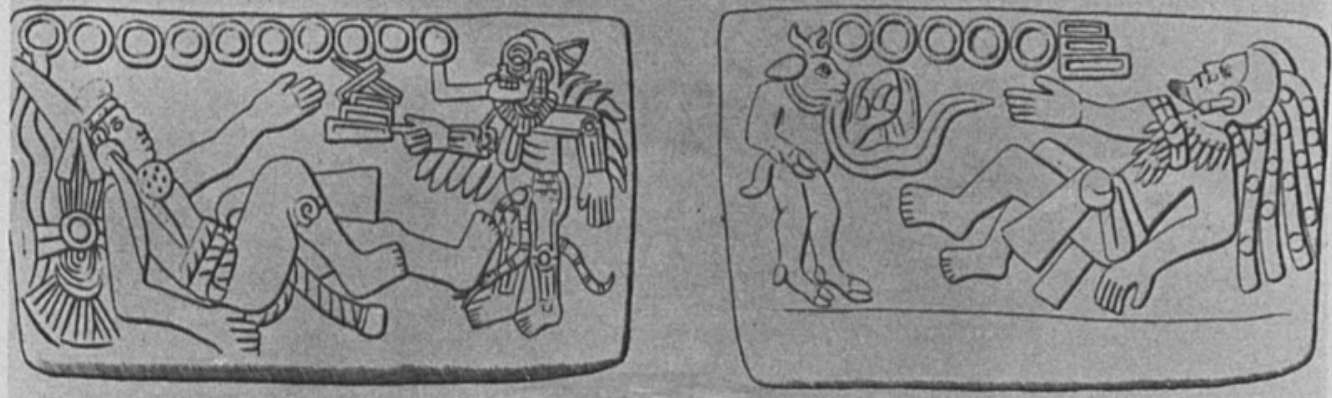

Figura 4. Bilbao. Monumento 13 y 14 (Parsons, 1969; láminas 42 a y b). 


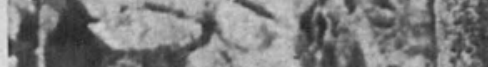

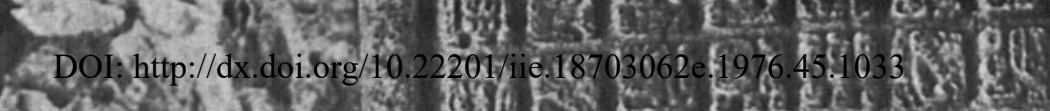

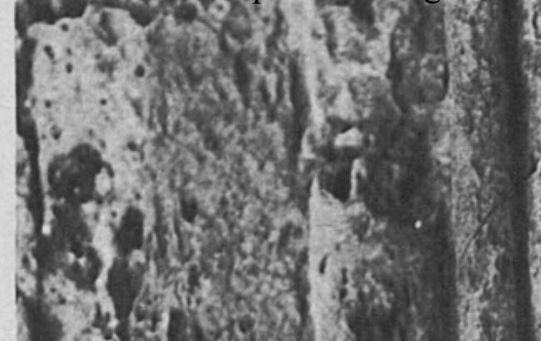
F.

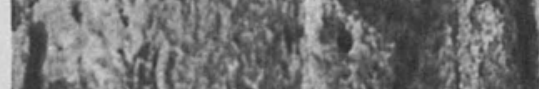
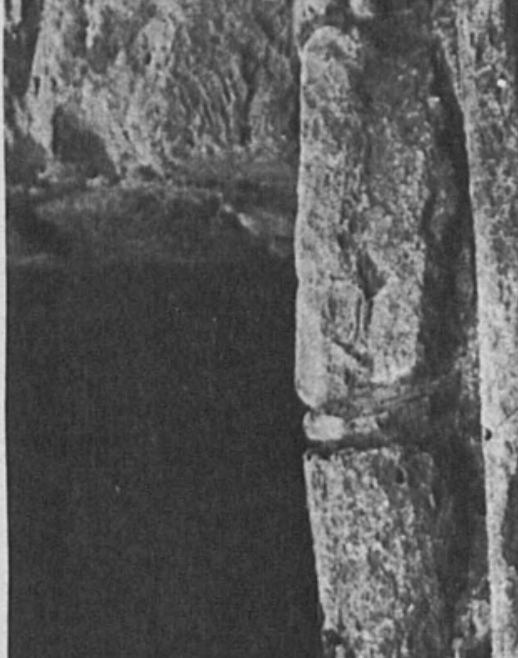

M.

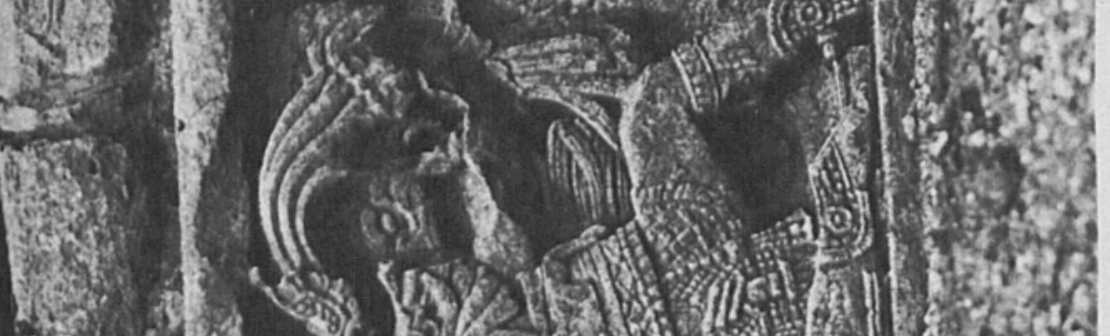

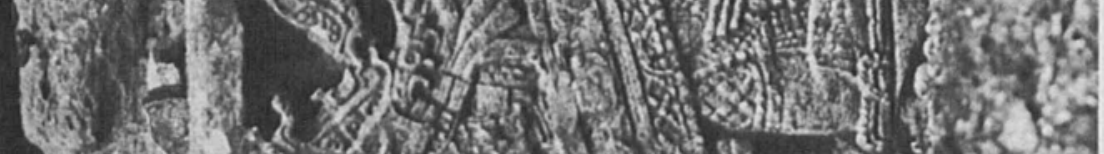

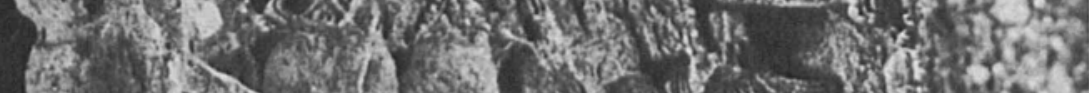
- 212 . 15

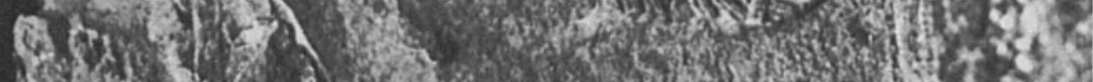
(1)

(m)

(x)

$4 x+3$

1.t.

Now on

(x)

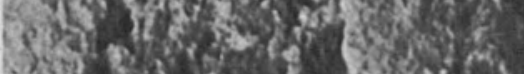
2. $10 \times 102$

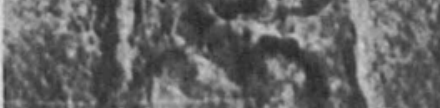

Pating 
DOI: http://dx.doi.org/10.22201/iie.18703062e.1976.45.1033
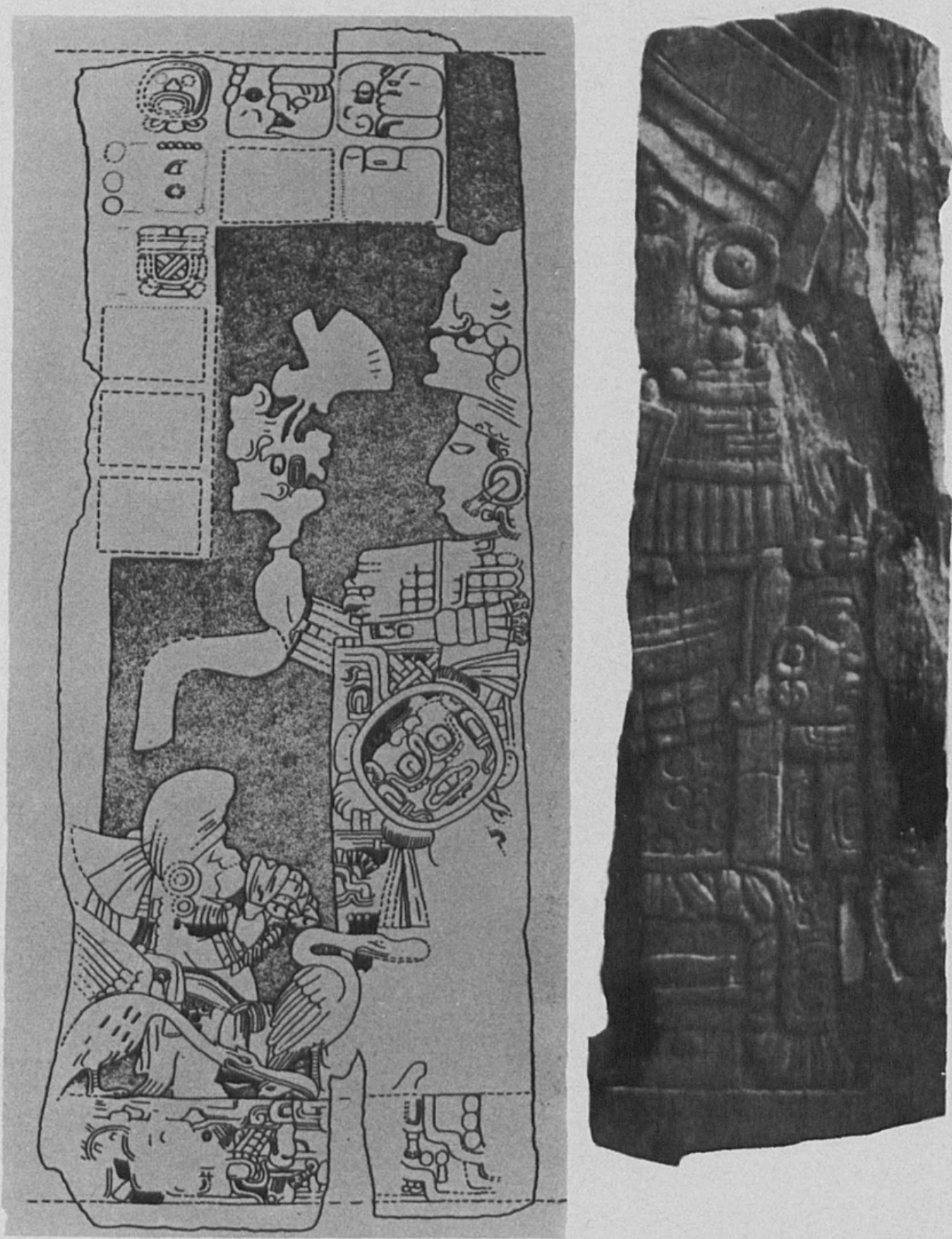

Figura 6. Tikal. Dintel de la estrada 10 (Satterthwaite, 1969 , figura $37 \mathrm{~b}$ ).

Figura 7. Tikal. Dintel 3. Templo 1. Detalle viga a (Satterthwaite, 1969, figura 14). 


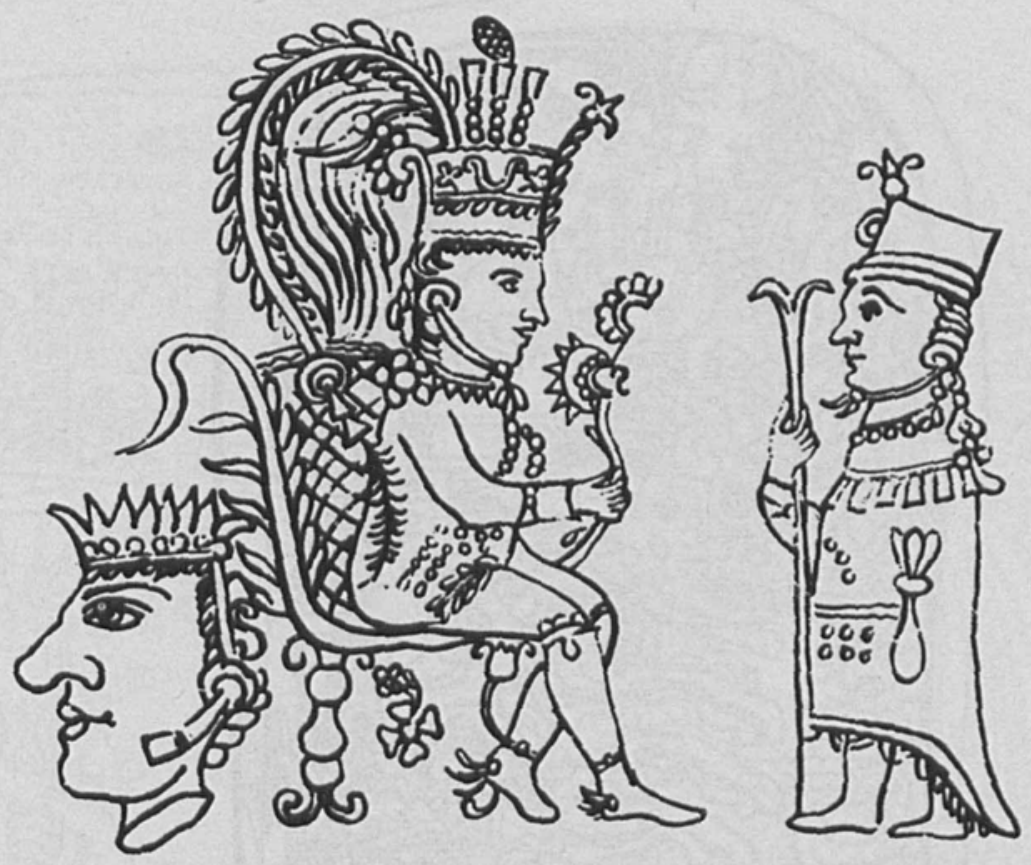

Figura 8. Tikal. Dintel 3. Templo 1. Dibujo según Ritter, 1833, viga a (Satterthwaite, 1969, figura 21a).

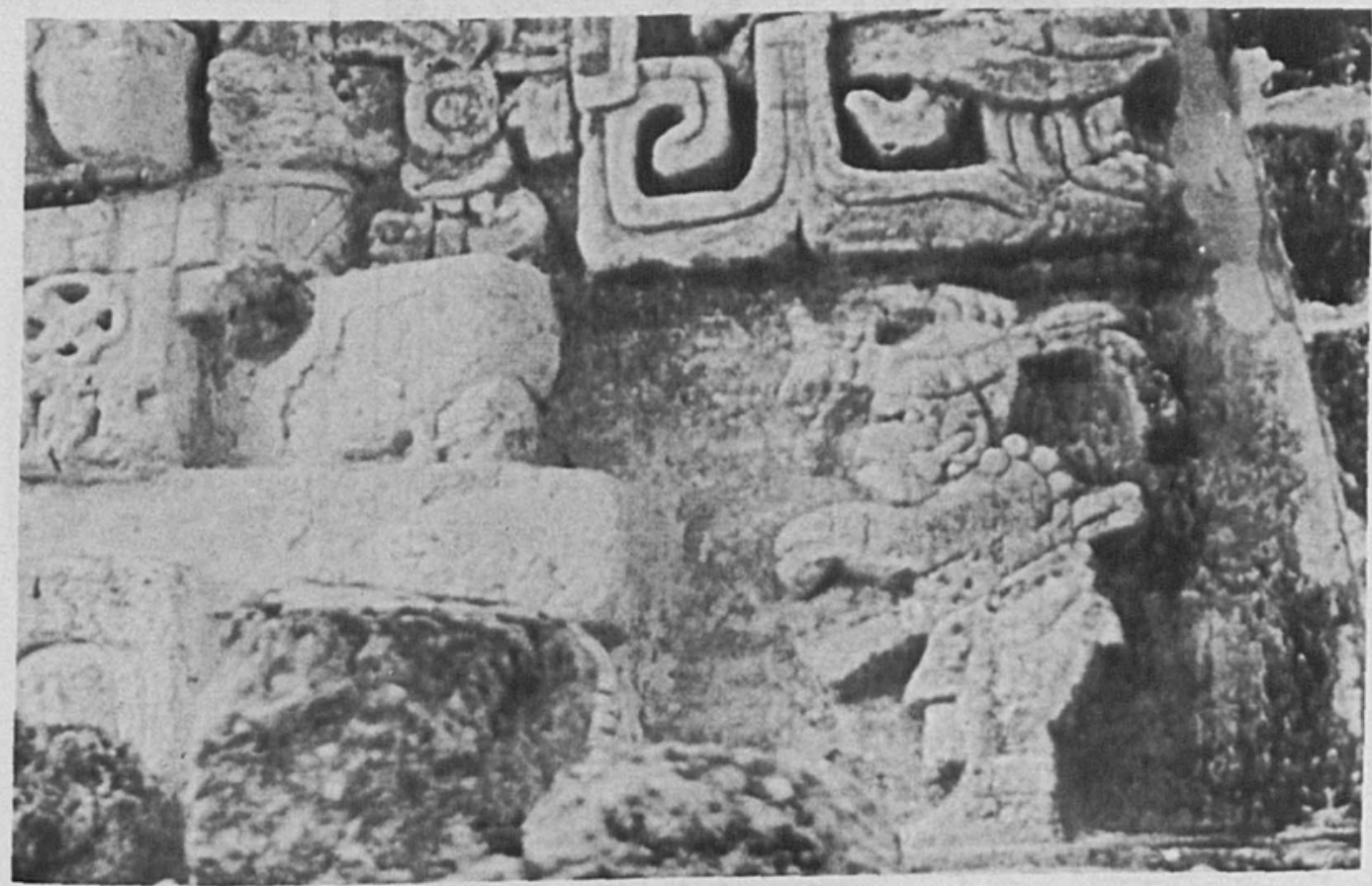

Figura 9. Tikal. Relieve en un edificio de la Acrópolis Central. (Foto. Cortesía de la señorita Andy Seuffert.) 


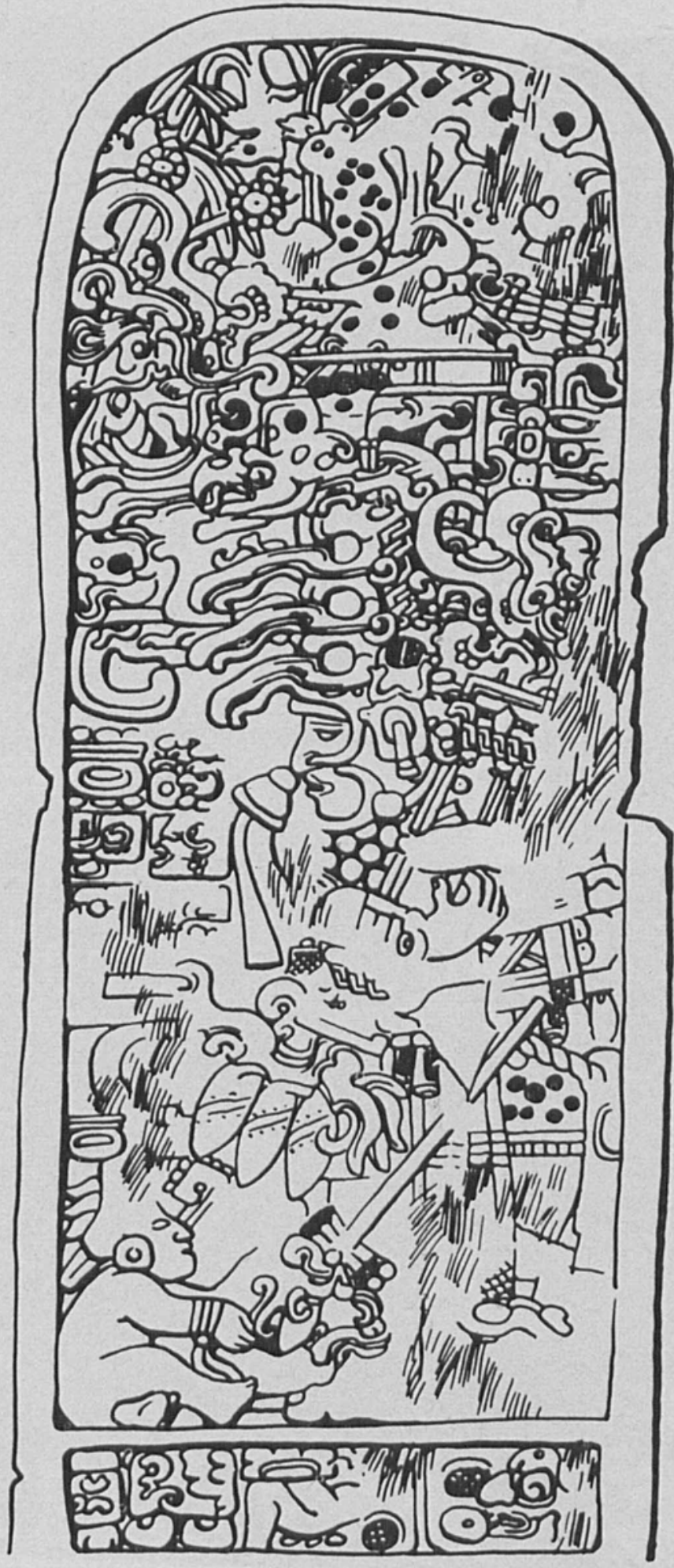

Figura 10. Yaxhá. Estela 13 (Robicsek, 1975, figura 199). 


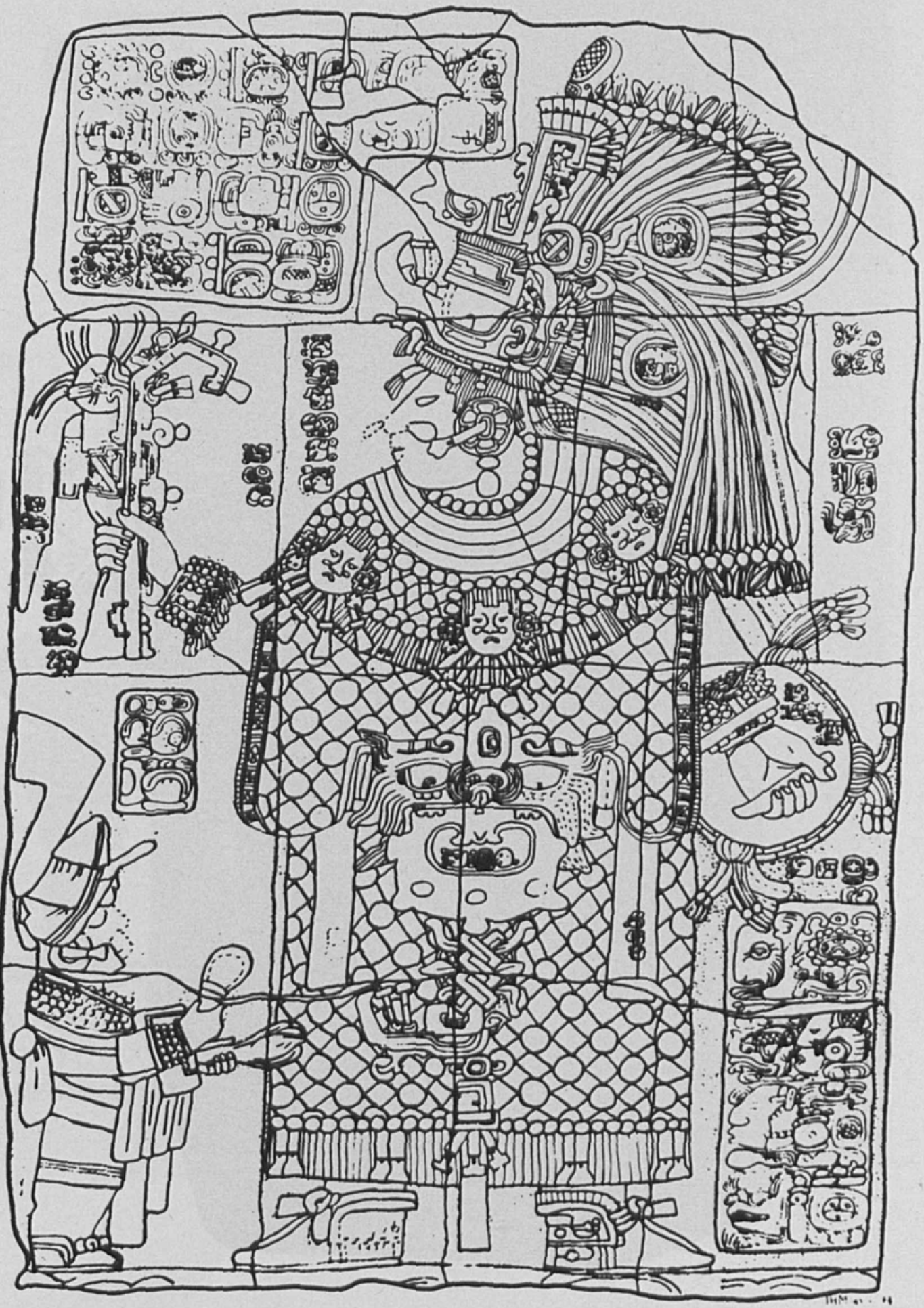

Figura 11. Calakmul. Estela 1 (Miller, 1974, figura 2). 
DOI: http://dx.doi.org/10.22201/iie.18703062e.1976.45.1033

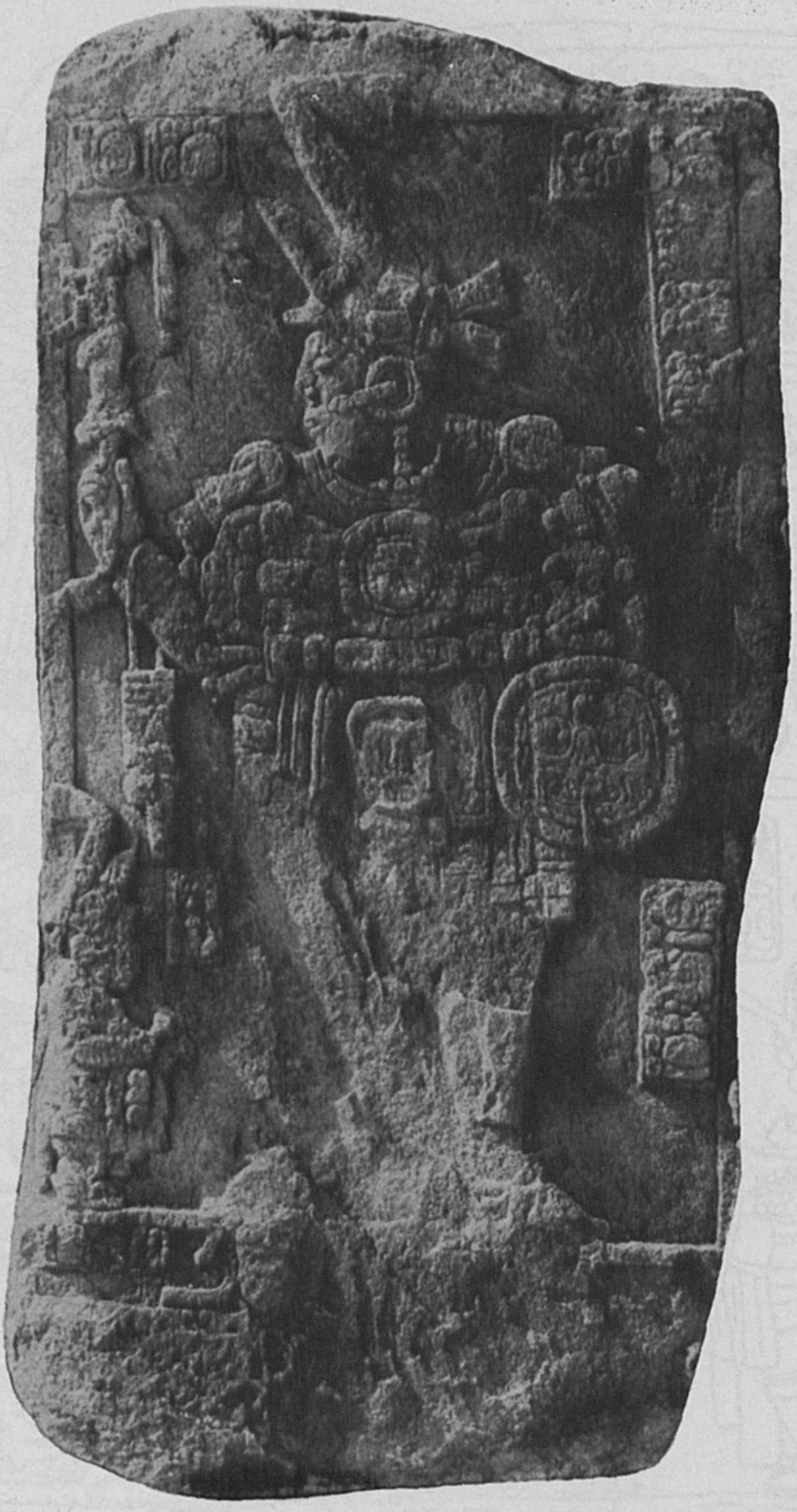

Figura 12. Calakmul. Estela 89 (Ruppert y Denison, 1943, lámina 53b). 
DOI: http://dx.doi.org/10.22201/iie.18703062e.1976.45.1033

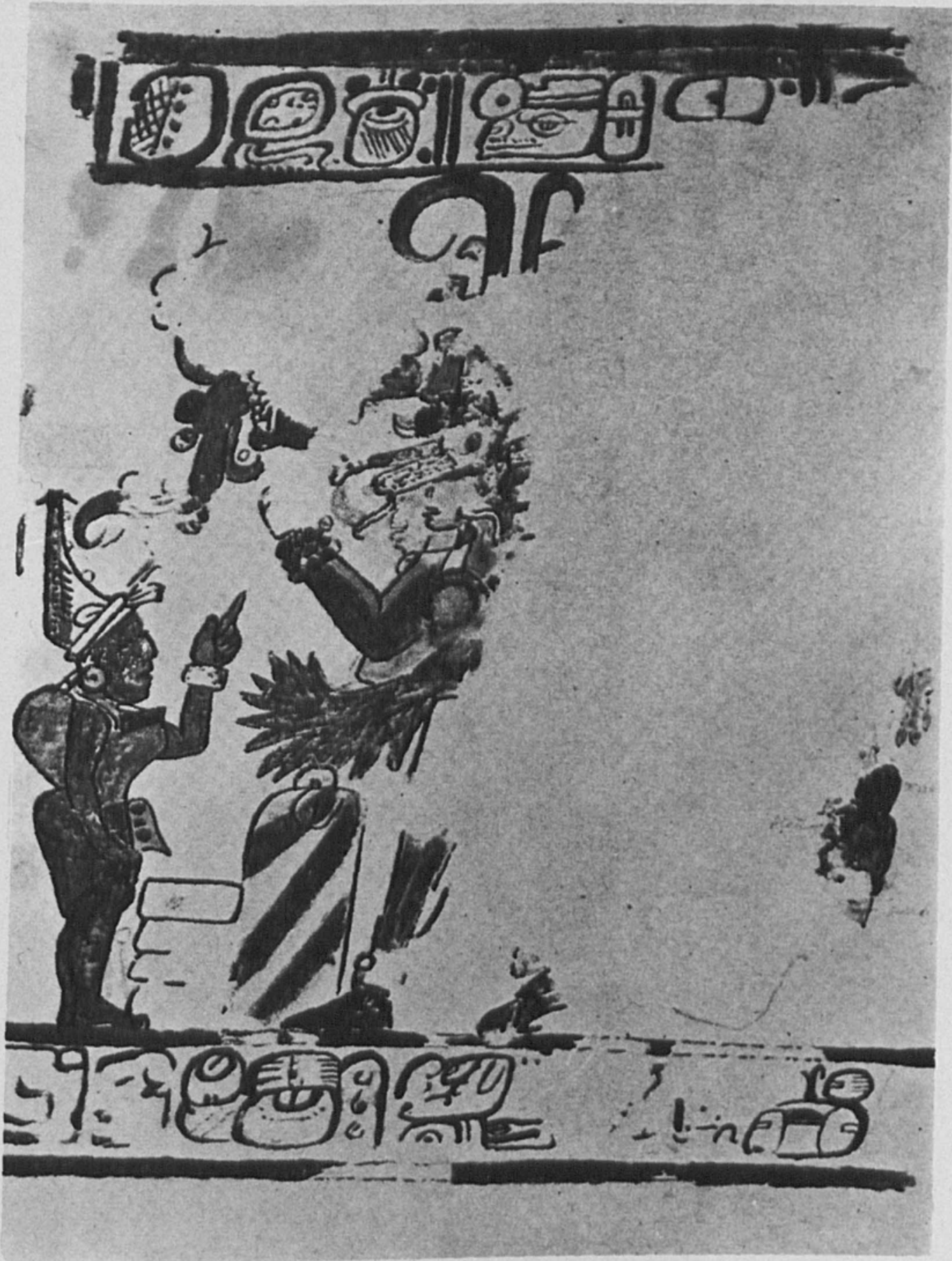

Figura 13. Sacnité. Pintura de la bóveda (Thompson, 1973, figura 1). 
DOI: http://dx.doi.org/10.22201/iie.18703062e.1976.45.1033

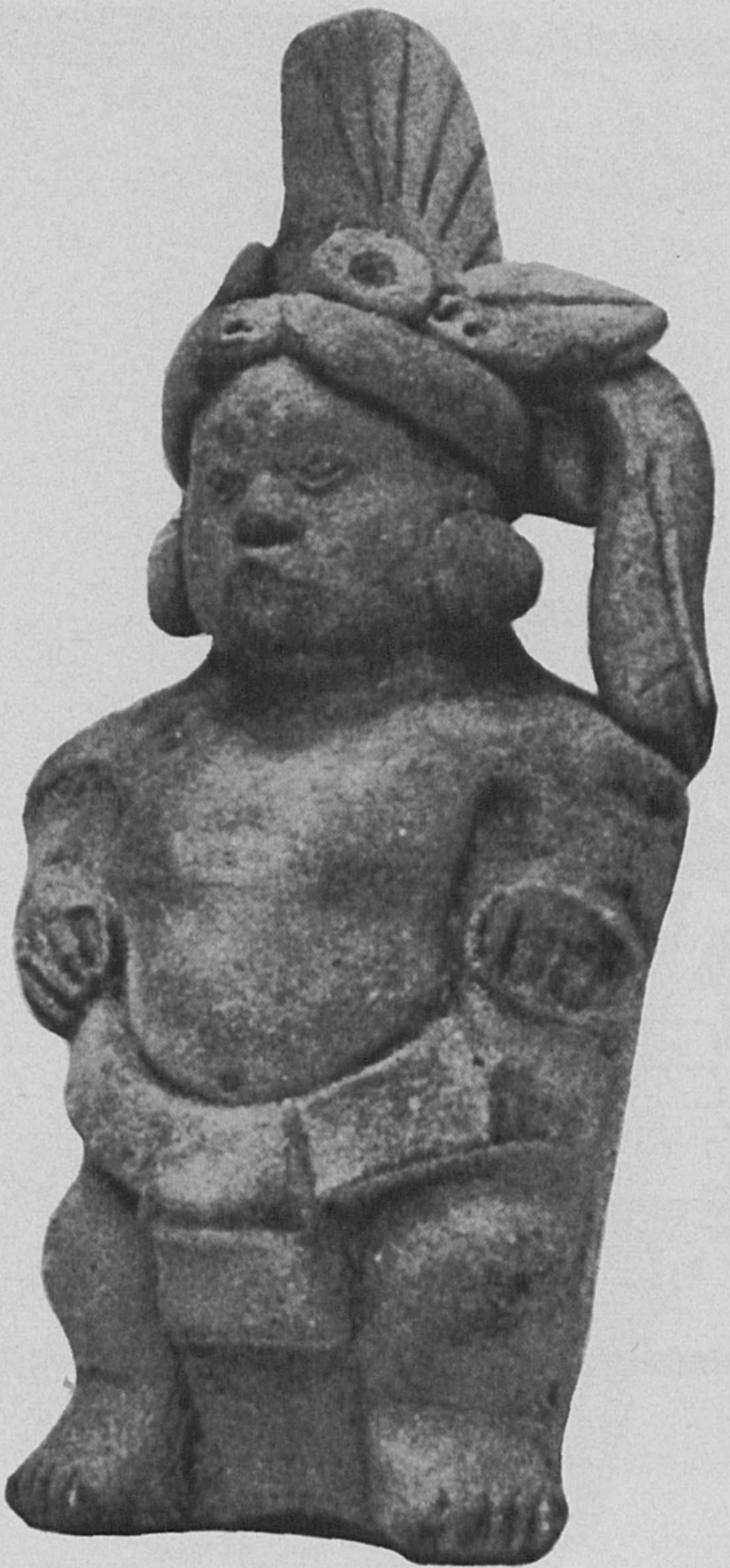

Figura 14. Tabasco. Escultura de barro (Kelemen, 1956, lámina 133d). 
DOI: http://dx.doi.org/10.22201/iie.18703062e.1976.45.1033

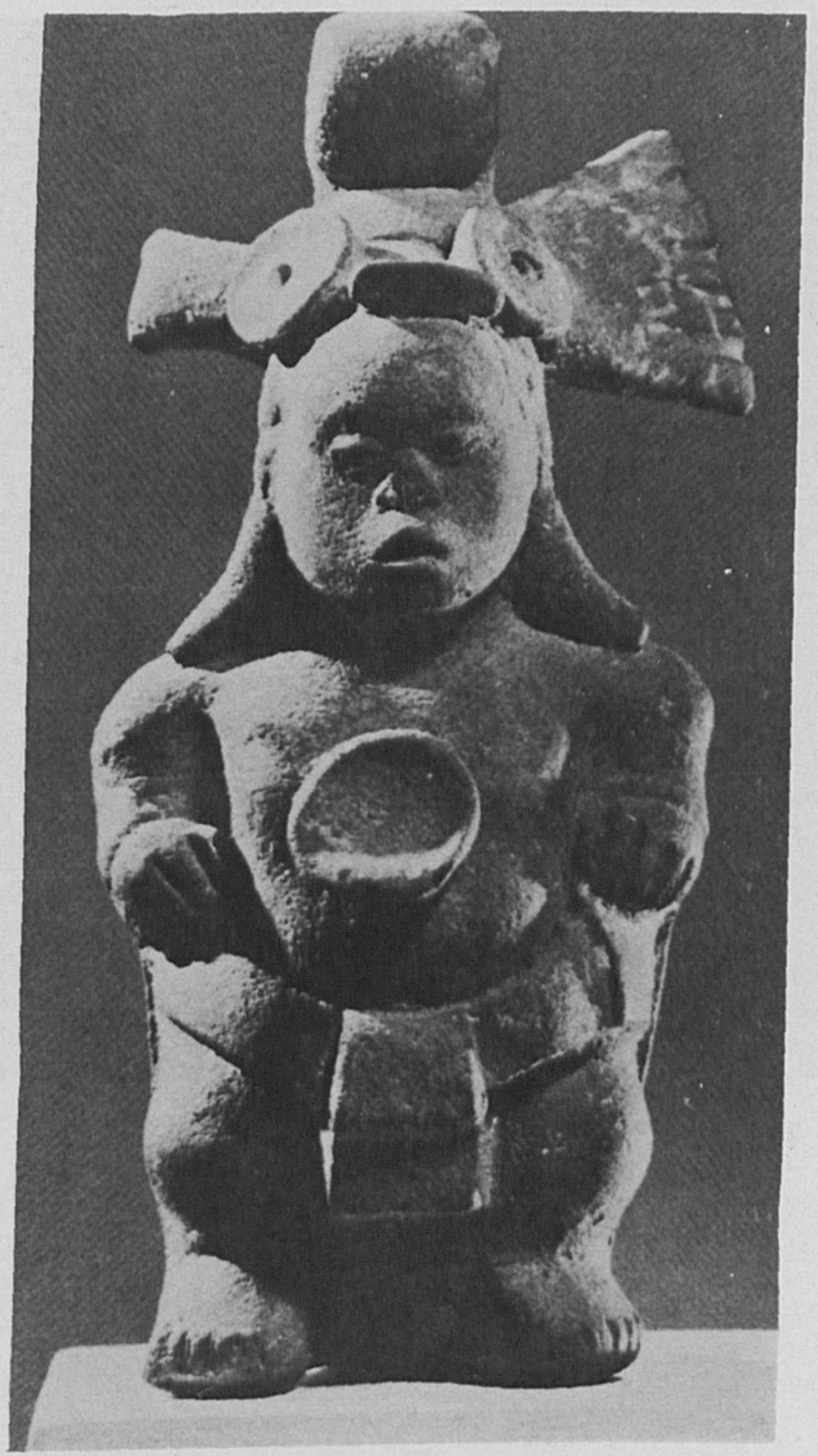

Figura 15. Jaina. Escultura de barro (Easly + Scott, 1970, figura 180). 


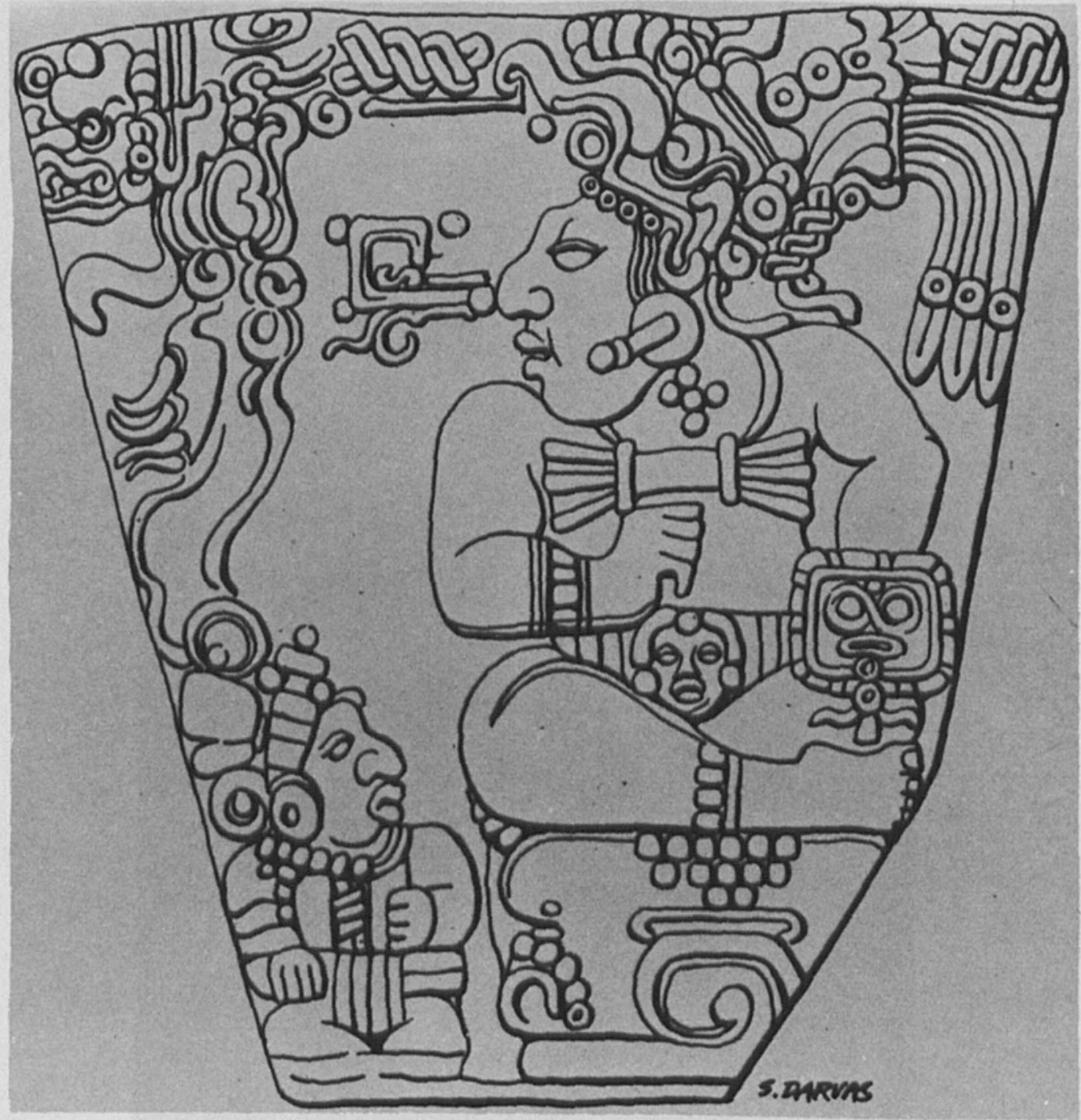

Figura 16. Copán. Placa de jade (Robicsek, 1975, figura 278). 
DOI: http://dx.doi.org/10.22201/iie.18703062e.1976.45.1033

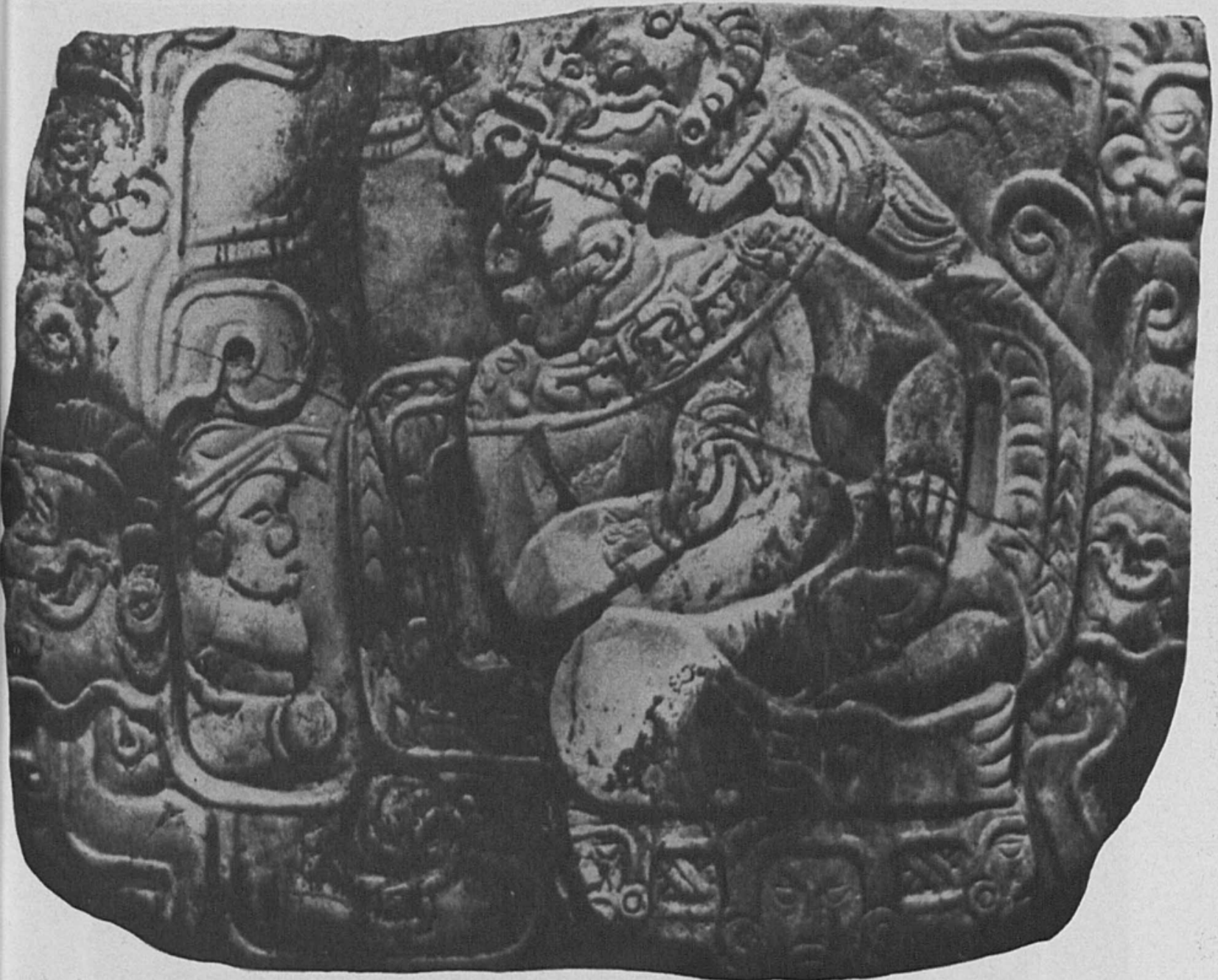

Figura 17. Nebaj. Placa de jade (Coe, 1966, lámina 66). 
DOI: http://dx.doi.org/10.22201/iie.18703062e.1976.45.1033

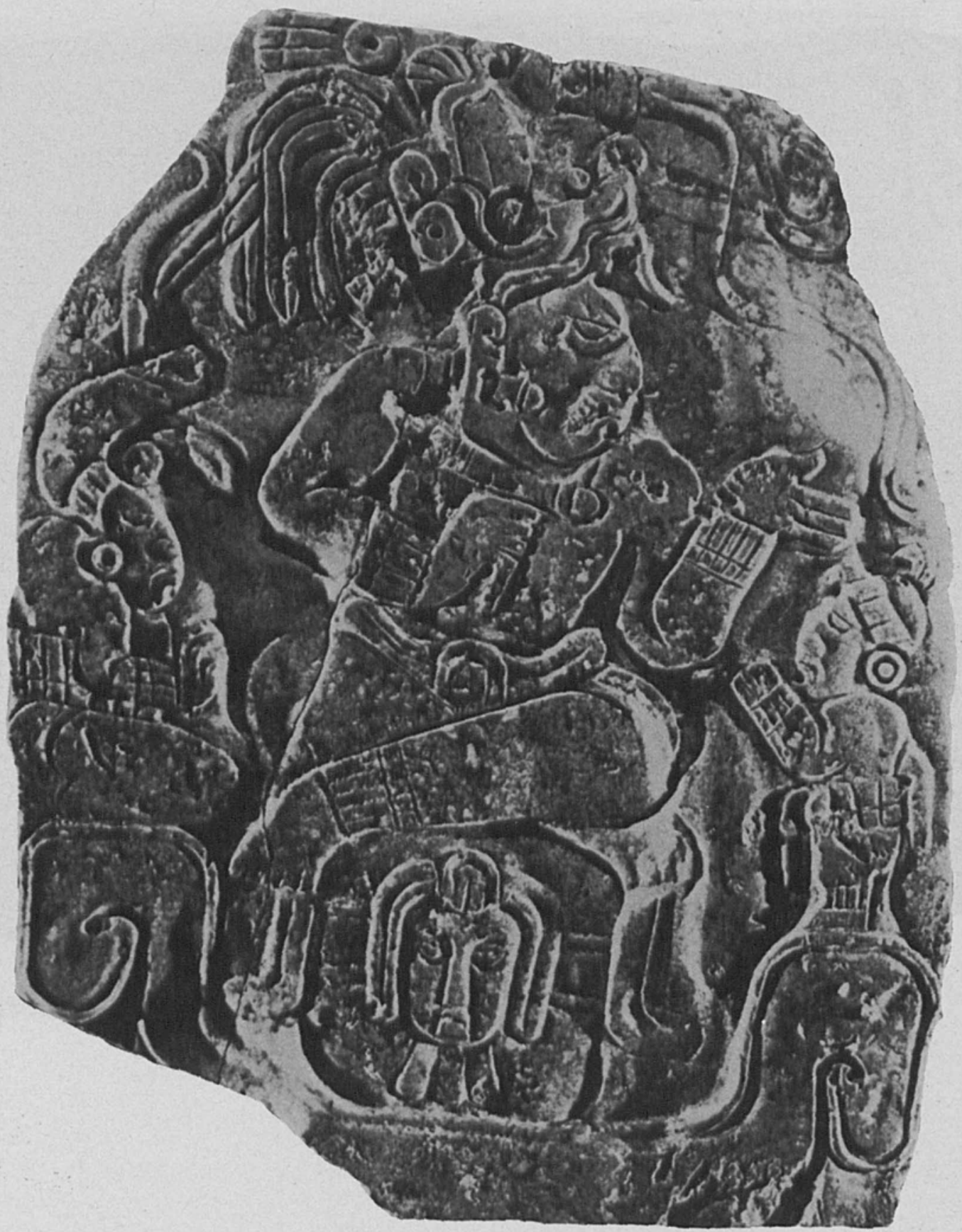

Figura 18. Zona maya. Laca de jade (Eckolm, 1970, página 112). 


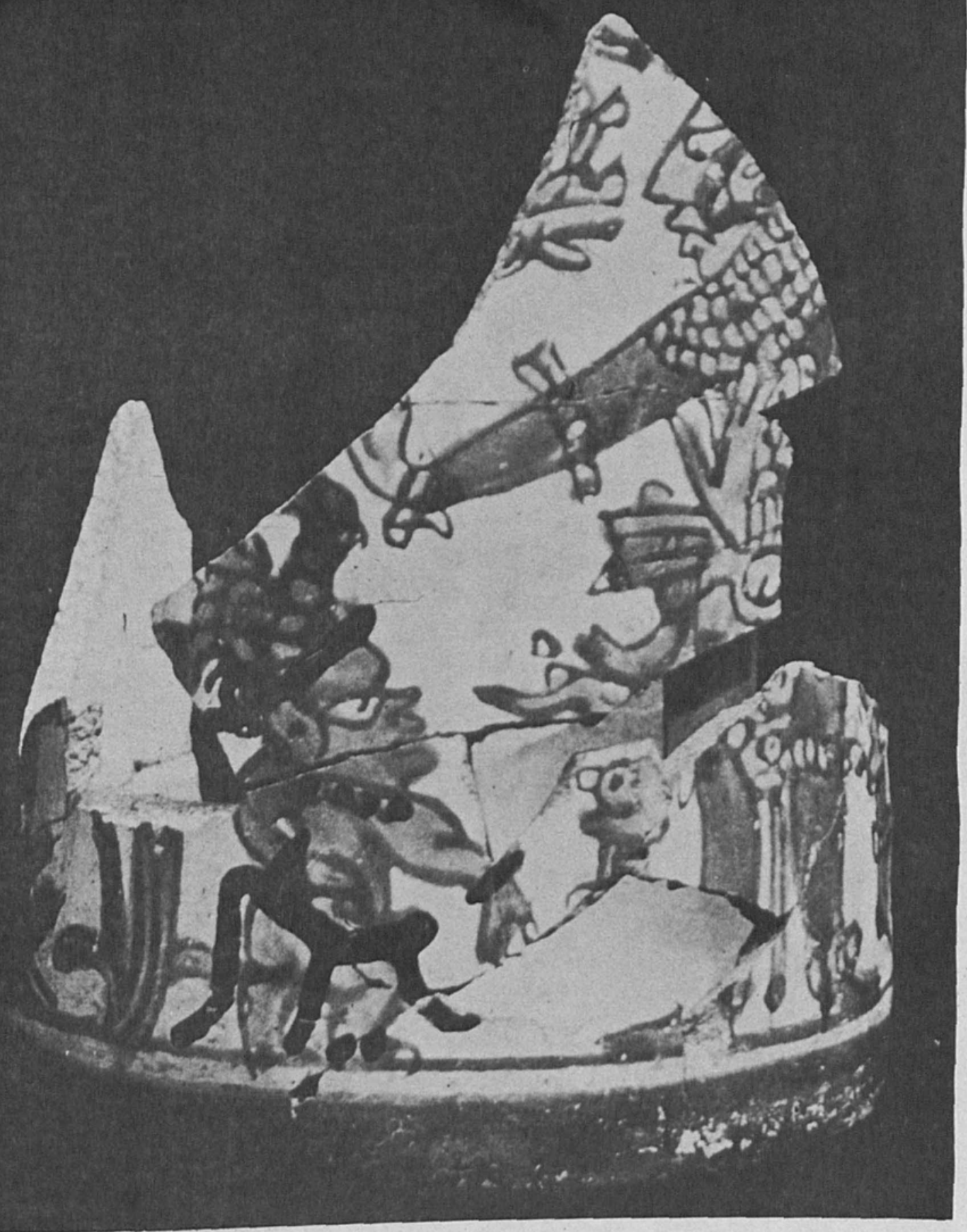

Figura 19. Uaxactún. Fragmento de vaso (Smith, 1955, volumen II, figura 2). 


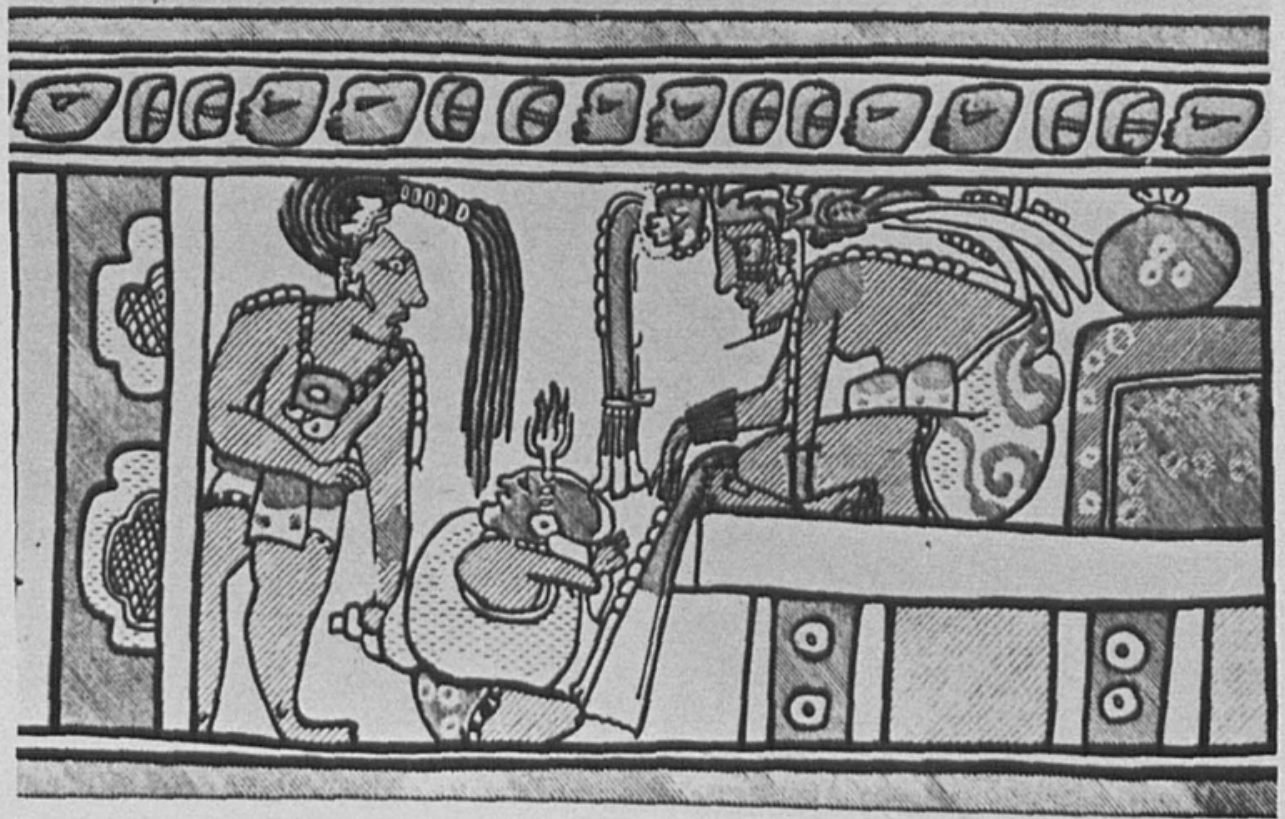

Figura 20. Tikal. Vaso (Coggins, 1975, figura 127).

Q

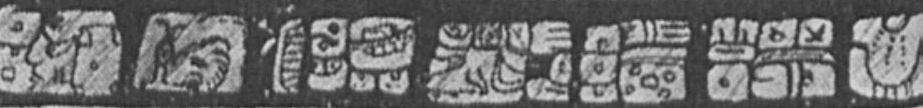

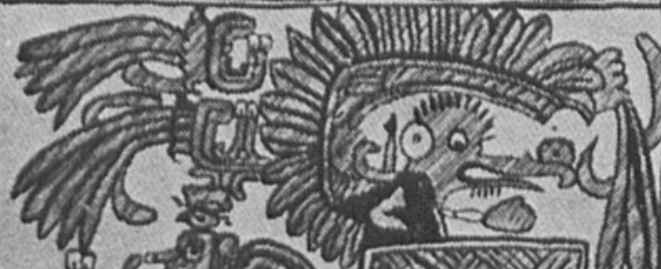
or

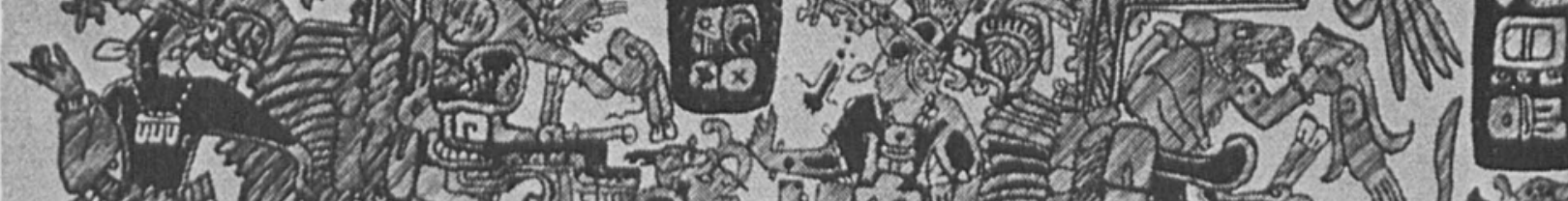

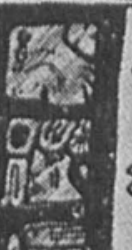
$4(6)$ (6)

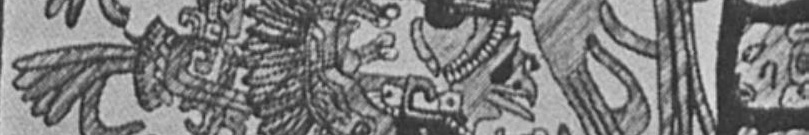

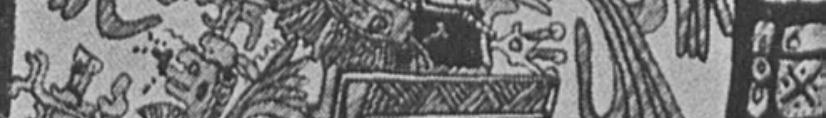
2.

Figura 21. Holmul. Vaso (Merwin y Vaillant, 1932, lámina 30c). 


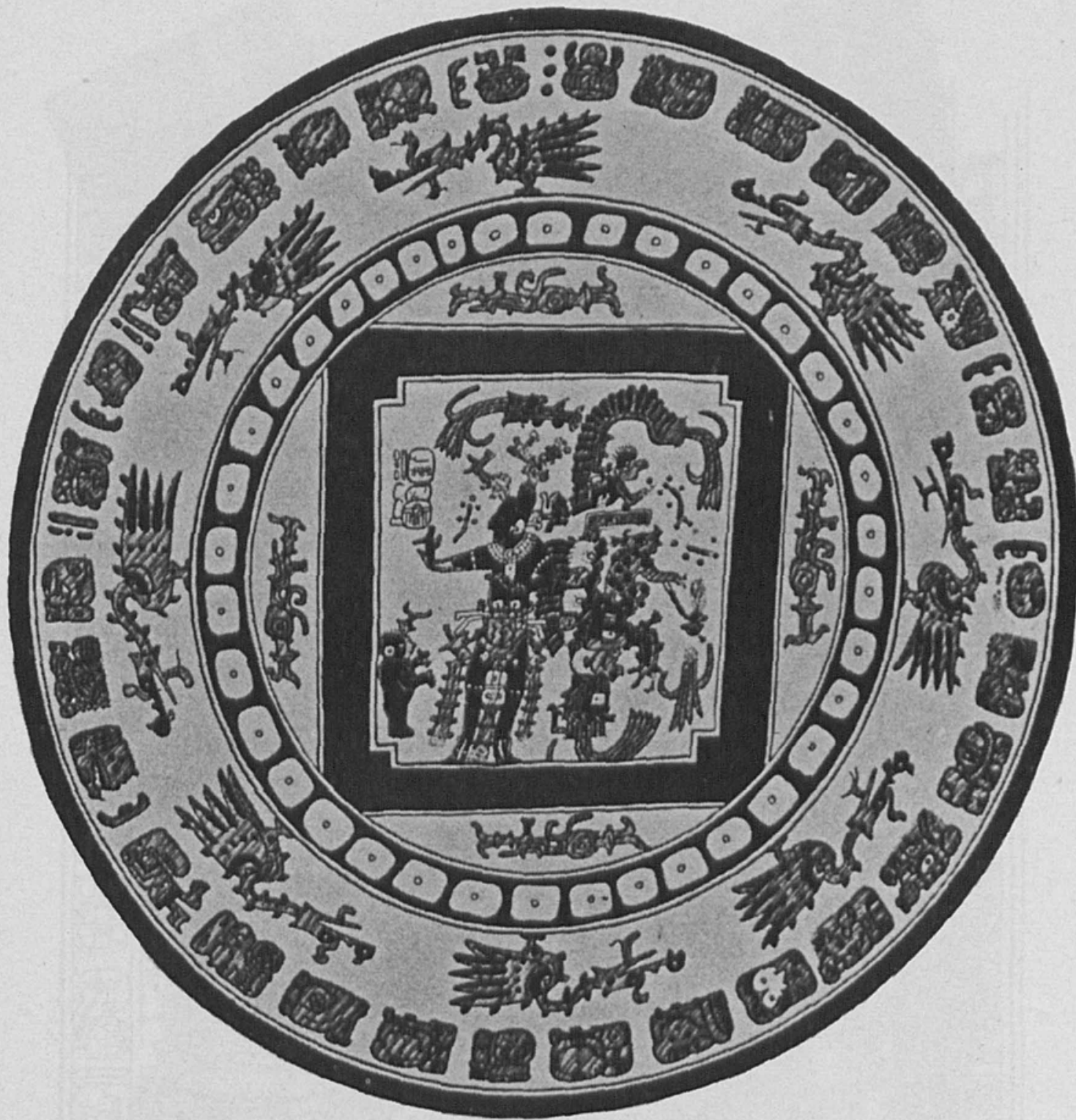

Figura 22. Holmul. Plato trípode (Merwin y Vaillant, 1932, lámina 29c). 


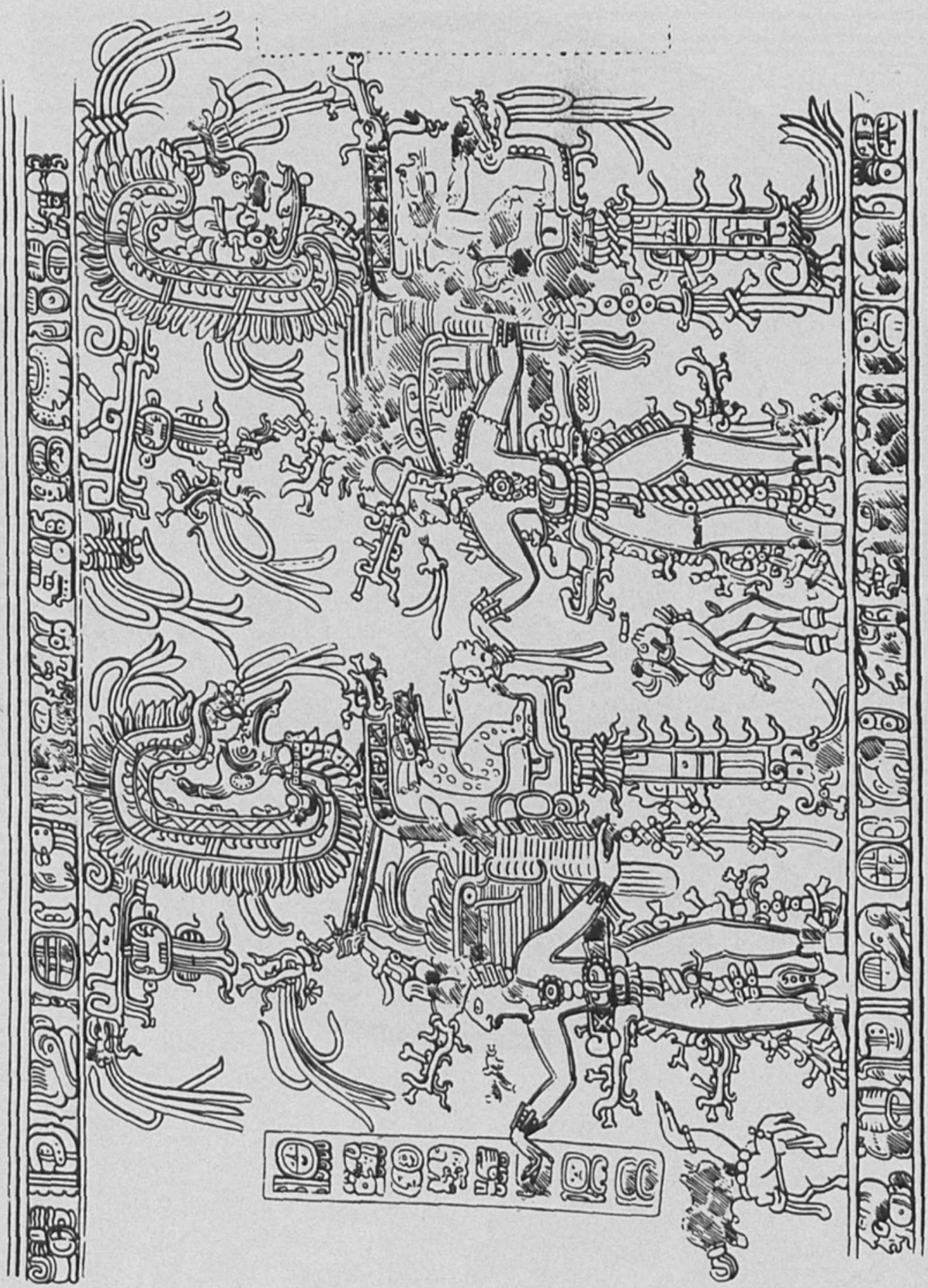

Figura 23. Yalloch. Vaso (Kubler, 1969, figura 56). 
DOI: http://dx.doi.org/10.22201/iie.18703062e.1976.45.1033

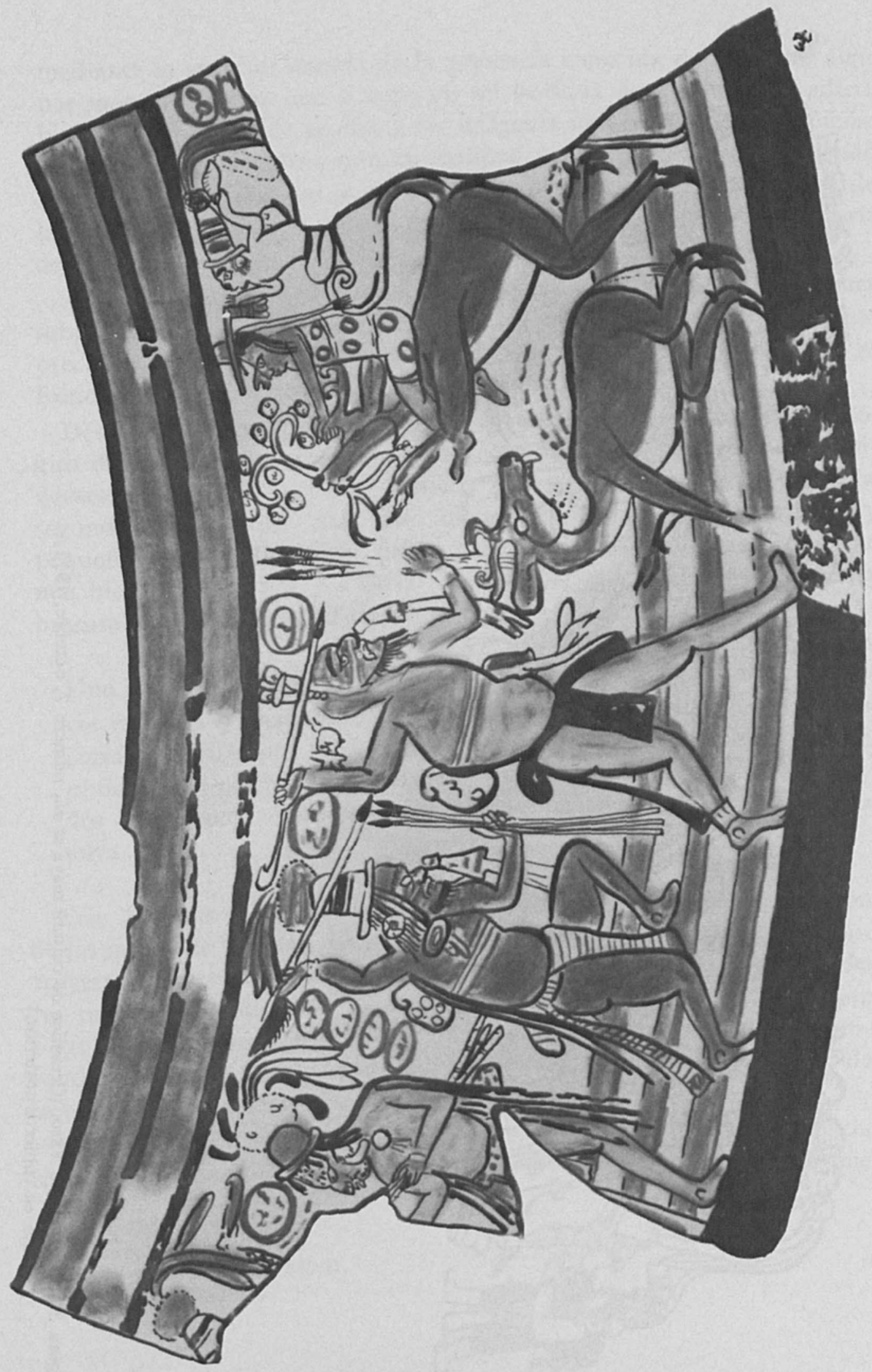

Figura 24. Actum Balam. Vaso (Pendergast, 1969, figura 12). 
DOI: http://dx.doi.org/10.22201/iie.18703062e.1976.45.1033
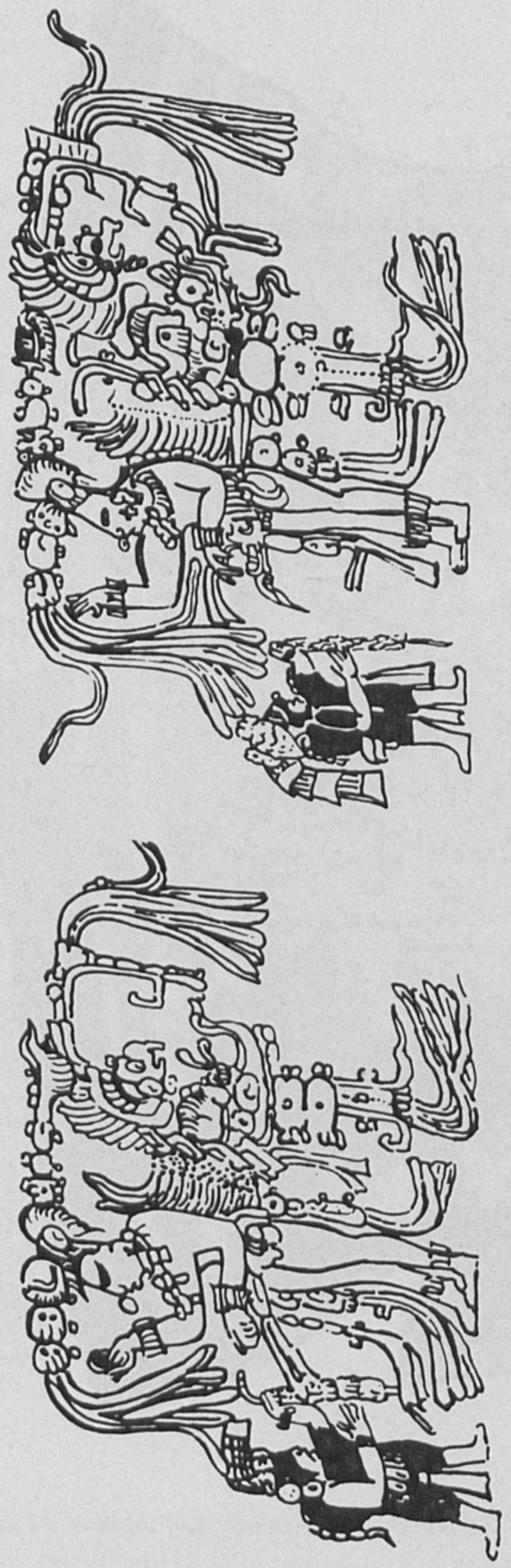

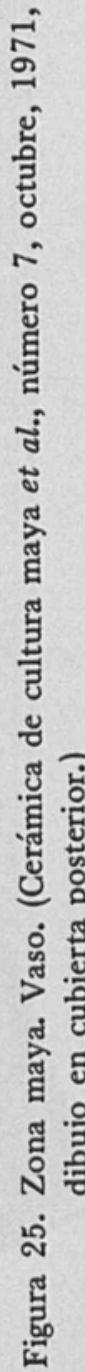


mediante la revisión somera de la presencia conocida de niños en algunos monumentos ya que si cupo en mí la duda de que pudiese adscribirle el calificativo de enanos a las imágenes que en este trabajo pienso darles categoría de tales y que, en realidad, las estuviese yo confundiendo con la de niños. Con un margen de seguridad bastante amplio estas de las que a continuación me ocuparé pueden ser adscritas a la categoría de enanos.

Antes de entrar en el tema quisiera hacer unas breves observaciones sobre la presencia del enano en otras regiones de Mesoamérica la que precedió en el tiempo la implantación de este motivo en el complejo iconográfico del clásico tardío maya.

Desde 1942, Caso y Covarrubias incluyeron en la clasificación tipológica de las imágenes en el arte olmeca, la de figuras que podrian considerarse de niños o de enanos. Ambos, sin embargo, se inclinaron por la segunda designación. Asf, Caso dice que se trata de "figuras muy pequeñas, que pudieran ser niños, pero que quizá debamos considerar más bien como enanos" " y Covarrubias se extiende más en el problema buscando su posible significación simbólica:

Uno de los tipos más característicos de objetos "olmecas" es una especie de niño o enano, con la cabeza bulbosa, ventrudo, con piernas cortas, casi siempre flexionadas y con los brazos sobre el pecho en puño. Son tipos burlones y traviesos, frecuentemente deformes y lisiados y parecen representar los enanos, duendes y espíritus de la selva...s

Eric Thompson, años más tarde en relación a los mitos de creación de los mayas de Yucatán asienta que los enanos (los zayamuincob) construyeron las actuales ciudades arqueológicas y que tenían grandes poderes mágicos. ${ }^{\circ}$ Anders en su estudio sobre la religión maya se refiere a los $A h^{\prime} T$ up enanos, según los pueblos de Belice, que viven en la profundidad de los bosques; se trata de seres pacíficos y receptores de ofrendas en las ceremonias agrícolas. 7

De las observaciones anteriores, las cuales parecen extenderse hacia creencias similares en otras regiones de Mesoamérica puede decirse que

4 Caso, 1942, p. 42.

5 Covarrubias, 1942, p. 47.

6 Thompson, 1970, pp. 340.41.

7 Anders, 1965, p. 239. 
al enano se le adjudicaron poderes mágicos, además de ser, en general, un personaje no violento y burlón. Características que curiosamente lo equiparan con el correspondiente duende o gnomo de la cultura occidental.

Una vez asentada la remota presencia del enano en la plástica olmeca y las observaciones que a la luz de creencias más recientes Covarrubias le dio a estos seres y la similitud de éstas en otras regiones de Mesoamérica, incluyendo la maya, considero de interés presentar algunas observaciones que proponen al enano en una posible asociación ritual con el sacrificio humano, que me parece de particular interés.

Durante el Clásico Temprano en la región de Cotzumalhuapa en la costa del Pacífico de Guatemala la escultura del área se significa principalmente por representaciones de jugadores de pelota y la asociación explícita de éstos con el sacrificio humano por decapitación. En varias de estas representaciones, en las estelas 1 y 3 de Bilbao así como en el Monumento 21 y en lápidas de contenido no sacrifical como las 14 y 15 de Bilbao aparecen figuras de proporciones mucho más pequeñas que las de los personajes principales; estas figuras han sido interpretadas como de enanos, aunque cabría la posibilidad de que su tamaño pequeño se debiese a requerimientos compositivos o simbólicos y no al deseo expreso del artista por registrar la imagen real de un tipo humano específico: el enano (figuras 1, 2, 3, 4).

La duda respecto a la presencia de enanos en el arte de Bilbao sería difícil de despejar de no contar con el reciente descubrimiento en Yaxchilán, en el corazón del área central maya, de unos escalones esculpidos en la plataforma del Templo 33 perteneciente al Clásico Tardio en los que aparecen relieves con jugadores de pelota, la pelota misma y un amplio registro jeroglifico. Agradezco al arqueólogo Roberto Garcia Mol el haberme facilitado fotografias de dichos relieves. En uno de estos escalones la escena se amplia y, además de los elementos antes mencionados, aparecen dos regordetes enanos de casi idéntico aspecto (figura 5) . El sentido de la composición es como en Bilbao, también de violencia, porque el relieve que decora la gran pelota a un lado del jugador lujosamente ataviado es la de un prisionero atado cuyo contorsionado cuerpo revela dramáticamente su definitivo estado de sometimiento. ¿Qué papel juegan los enanos en esta escena, además del de testigos de alto rango como lo indican los símbolos venusinos que decoran sus cuerpos y el tocado serpentino que corona sus grandes cabezas? No lo sé, pero por prueba indirecta y brincando las barreras del tiempo y de la geografía 
podria relacionarse a Yaxchilán con la región de Cotzumalhuapa en la interpretación similar de los monumentos mencionados o sea que a la luz del arte de esta última región podamos suponer que el prisionero en Yaxchilán es una víctima destinada al sacrificio humano por deca. pitación y que la asociación enano-jugador de pelota en Yaxchilán permita declarar que los pequeños acompañantes de los personajes en Bilbao son efectivamente enanos. En los relieves de Yaxchilán los enanos parecen entrar en el contexto ritualista de la escena como acompañantes destacados por los atributos simbólicos con que fueron representados, Ios cuales los despojan de su precaria condición física en el orden de los seres mortales y les otorgan una dignidad mágico-religiosa en consonancia con las imágenes de seres dotados con poderes sobrenaturales.

Además del par de enanos en el escalón esculpido de Yaxchilán, el muestrario de estos diminutos seres no deja de ser importante. A continuación presento una lista, sin pretender que sea exhaustiva, de los sitios y las obras que por su calidad artística y también documental considero de interés apuntar:

Tikal, Guatemala:

Dintel de la Estructura 10 (figura 6)

Dintel 3 del Templo 1 (figura 7) ${ }^{*}$ (nota 8)

Relieve en un edificio de la Acrópolis Central (figura 9)

Yaxhá, Guatemala:

Estela 13 (figura 10)

Calakmul, Campeche:

Estela 1 (Museo de Cleveland) (figura 11)

Estela 89 (figura 12)

Yaxchilán, Chiapas:

Escalón en la plataforma del templo 33 (figura 5)

Sacnité, Yucatán:

Pintura en piedra de cierre de bóveda (figura 13)

Tabasco:

Escultura pequeña de barro (figura 14)

Jaina, Campeche:

Escultura pequeña de barro (figura 15) * (nota 9)

Copán, Honduras:

Placa de Jade (figura 16)

Nebaj, Guatemala:

Placa de jade (figura 16) 
Zona Maya:

Placa de jade (figura 18)

Cerámica:

Uaxactún, Guatemala:

Fragmento de vaso (figura 19)

Tikal, Guatemala:

Vaso (figura 20) * (nota 10)

Holmul, Guatemala:

Vaso (figura 21)

Plato trípode (figura 22)

Yalloch, Belize:

Vaso (figura 23)

Actún Balam, Belize:

Vaso (figura 24)*(nota 11)

Zona Maya:

Vaso (Galería Merrin, Nueva York) (figura 25)

En Tikal, el dintel de la estructura 10, uno de los edificios que por sus numerosos cuartos han sido denominados palacios, está constituido por cinco grandes vigas de las que se conservan las dos centrales en las que está esculpido, respectivamente, un personaje de pie ricamente ataviado y frente a él la figura de un viejo enano quien en cada mano sostiene un pequeño ramo de tallo corto compuesto por una flor en botón o un fruto y varias hojas que se deslizan al frente como impulsadas por el movimiento de la mano. A los pies del enano aparecen dos gansos de elegante diseño y postura, uno de ellos con un pescado en el largo pico. Hombres y aves están parados en una plataforma ricamente decorada con un intrincado diseño, parcialmente perdido, el que parece representar un mascarón formado básicamente por volutas y elementos circulares. Un cartucho de glifos en forma de $\mathbf{L}$, completa la composición en la parte superior.

El contexto de la representación es indudablemente de gran fastuosidad y solemnidad, lo atestiguan el jerarca, con su rico atuendo, enfatizado por el gran escudo decorado con la efigie del dios solar que mete en su brazo izquierdo y por el cetro maniquí de base flexible que sostiene en la mano derecha. Pero no solamente la riqueza suntuaria está manifiesta en el dignatario, sino que ésta se observa también en su acompañante, el enano, quien porta un traje decorado con puños y lazo al 
frente, orejera de doble disco perforado y se anuda la cabeza deforme con un paño de tela que se amarra atrás y cae en un gran lazo; además las dos bellas aves que, a sus pies, casi parecen envolverlo, subrayan por decirlo así, la indudable dignidad social que el personaje tuvo en un capítulo de la historia de Tikal. La fecha del dintel es 9.15.10.0.0: 750 d. C. 8

Es extraordinariamente interesante encontrar que en Calakmul el importante centro maya en la región sur del Estado de Campeche se hubiesen erigido dos estelas, la 89 y la 1 (esta última actualmente en el Museo de Cleveland y atribuida por Miller al sitio) ${ }^{9}$ con el mismo conjunto iconográfico del dintel de la Estructura 10 de Tikal.

La única diferencia con el dintel de Tikal es que las dos figuras principales en Calakmul están representadas con el cuerpo en posición frontal. Jeffrey Miller identificó como personaje femenino a la imagen principal de la Estela 1 de Calakmul. ${ }^{10}$ Tanto el dintel de Tikal como los dos monumentos de Calakmul pertenecen a la misma época, la que estilísticamente ha sido denominada por Tatiana Proskouriakoff, ornamental, y cuyas fechas aproximadas van de 692 a 751 d. C. En las estelas de Calakmul parece haber una clara alusión al nombre del enano acom. pañante por los pequeños cartuchos de jeroglíficos inscritos cerca de la figura.

Los tres enanos, en cada uno de los monumentos mencionados, muestran al dignatario un conjunto de elementos vegetales cuya identificación como tales parece ser más evidente en el dintel de Tikal, ya que en los de Calakmul pudieran interpretarse como sonajas. Sin embargo, a la luz de las de Tikal asumo que se trata del mismo elemento. Estas

8 Registro este dintel porque se le ha adjudicado el calificativo de enano a uno de los personajes de la escena (Fig. 7), su identificación, sin embargo, es dudosa porque, a pesar de su corta estatura muestra proporciones y rasgos físonómicos armónicos que difieren de los que caracterizan al enano. El aspecto físico de la figura me hace pensar que se trata más bien de un jovencito en cuyo rico atuendo que incluye piel de jaguar y una cabeza-trofeo parece indicarse su relación de linaje con el personaje adulto que está frente a él. En el Reporte No. 6 de la Universidad de Pennsylvania sobre los dinteles esculpidos de Tikal se publica, sin discutirlo, el fan. tasioso dibujo que Lara tomó de Ritter de 1833 y en el que se identifica al personaje aludido como un enano (Fig. 8). El margen de duda sobre esta afirmación es, a mi juicio, muy grande.

9 El inventario de enanos en esculturas de barro de pequeño formato es más amplio. Sólo me interesa asentar la existencia de este tipo humano en una forma de repre. sentación escultórica típica del arte maya.

$10 \mathrm{El}$ pequeño personaje ha sido interpretado por Clemency Coggins como una figura que emerge de un caracol lo que explicaría su aspecto contrahecho. Yo me inclino a pensar que se trata de un enano. 
formas vegetales son, a mi parecer, representación de las hojas y el fruto del cacao. Si asi fuese los enanos pueden significar, dentro del contexto narrativo de la escena el papel de representantes o de emisarios de los grandes señores o de grupos sociales dedicados al cultivo o al comercio del importante producto. Esto explicaria la actitud digna y la suntuosidad que el artista les impartió dentro de cada escena. Las reflexiones anteriores permiten presuponer que, a pesar de su enanismo están investidos con alguna forma de autoridad social que les permite enfrentarse con naturalidad a los jerarcas de Tikal y Calakmul, respectivamente. Juzgo que su presencia en los monumentos, no es significativa de una categoría de linaje sino que su relación con los dignatarios fue por su oficio, por su actividad la cual pudo también poseer implicaciones de carácter mágico-religioso. Muchas de estas consideraciones se esclarecerian con un mayor conocimiento de los textos jeroglificos asociados a las imágenes.

Un caso similar al del dintel de Tikal y las estelas de Calakmul es el de la estela 13 de Yaxhá en el Petén guatemalteco con respecto a la indudable dignidad social del enano. En Yaxhá está posiblemente aún más enfatizado este aspecto porque el pequeño personaje, sentado a los pies del dignatario tiene consigo un mascarón simbólico, que ornamenta una vasija o incensario por el pequeño pedestal que se aprecia en su base. El mascarón se prolonga en un bastón o sonaja que toca la cintura de la figura principal. La asociación entre el enano y una imagen del mundo sobrenatural y de éstos con el jerarca a través de un objeto ritual revelan un contexto ceremonialista en el que posiblemente los poderes mágicos atribuidos al enano están, además, presentes.

Existe otra representación de un enano en Tikal. Se trata de un alto relieve en piedra, recubierto de estuco en la Acrópolis Central. Perteneció a la pared de atrás de uno de los templos (43 o 46) que fue tapiada por los propios mayas, descubierta en 1964 por Guillemin y vuelta a tapar durante los trabajos en el sitio realizados por la Universidad de Pennsylvania (comunicación personal y fotografia de la señorita Andy Seuffert). En este caso se trata de un enano que es también jorobado, representado de perfil con los brazos extendidos al frente. Nuevamente, como en los casos ya mencionados, impresiona la riqueza de su atavio: collar de cuentas, orejera y penacho corresponden a los tradicionalmente usados por los personajes de alta jerarquía. En la fotografía que pude obtener no hay otras representaciones figurativas que permitan especuIar sobre el significado que tuvo esta peculiar imagen de rostro simiesco. 
Únicamente, alguna, similar a la que propuse anteriormente en cuanto al alto status social que ciertos enanos parecen haber tenido en las ciudades mencionadas.

En pintura, en la piedra de cierre de una bóveda en Sacnité, Yucatán, la directa relación entre una figura de rango y el enano, en este caso, también jorobado, se hace aún más patente. El efecto de diálogo entre uno y otro personaje es evidente y la expresividad del mismo, curiosamente la da el enano por el gesto admonitorio con que se dirige a la figura principal.

El enano aquí, está pintado de rojo, viste maxtlatl con lazo decorado, lleva brazalete, pectoral y orejeras y se cubre la cabeza a la manera de los Tikal y Calakmul. Un bulto y otros objetos rectangulares superpuestos separan a las dos figuras, objetos que por su forma y posición parecen sugerir ser mercancias. En esta representación como en la del dintel de Tikal y las de las estelas de Calakmul, en la asociación entre el enano y la figura principal están presentes materiales y objetos que pudiesen tener un sentido comercial por lo que deduzco que existe la posibilidad de considerar que el enano, en estos casos, tuviese atribuciones relacionadas con operaciones de transacción. De ser así, vale la pena reflexionar sobre las dos aves que aparecen en el dintel de la Estructura 10 de Tikal y pensar que éstas se encuentran a los pies del enano no por razones simbólicas o decorativas sino de comercio, para ser vendidos por la belleza de su plumaje.

Es por supuesto imposible dejar de lado las consideraciones que pueden hacerse sobre el enano como un hombre que en las culturas mesoamericanas tuvo poderes mágicos y atributos que lo colocan en un nivel que trasciende definitivamente el humano para entrar en lo divino.

Eric Thompson se planteó la pregunta sobre el significado intrínseco del enano en la piedra de bóveda de Sacnité e hizo una breve referencia a su posible pero muy incierta asociación con ritos alucinógenos. El eminente investigador cita pasajes del Chilam-Balam de Manf y de Tizimín en las que se refiere el trance en el que entra el chilam para recibir la profecía del katún la cual le es comunicada a través de un duende. ${ }^{11}$ En esta ceremonia el chilam se ponía en el suelo y hablaba con voz gruesa, lo que le permite suponer a Thompson que estuviese bajo los efectos de una droga alucinógena. Encuentra una posible corresponden-

11. En el vaso de Actum Balam, una diminuta figura aparece montada en el cuello de un venado; su tamaño pudo obedecer a requisitos de la composición, por lo que tengo reservas respecto a su enanismo. 
cia con ceremonias de este tipo en dos representaciones en Catzumalhuapa, los Monumentos 13 y 14 a los que ya he hecho mención, en los que, respectivamente, aparecen figuras humanas recostadas frente a figuras más pequeñas de pie, en un caso, un hombrecillo con cabeza de muerte, en el otro con cabeza de venado cuyo contexto pudiese ser semejante al descrito por los libros del Chilam-Balam. Sin embargo, a mi juicio, es difícil aún decidirse en pro o en contra de estas suposiciones.

La hipótesis de Thompson aplicada a las manifestaciones de la plástica maya que he mencionado en párrafos anteriores podría significar que al enano se le hubiesen atribuido poderes de vaticinio y profecía, tan esenciales en el quehacer de las clases gobernantes mayas, y que su presencia en los monumentos reflejase precisamente la importancia que su cargo tenía dentro de las prácticas religiosas de la época: de ahí el registro tan realista y preciso de su imagen en los monumentos aludidos. Prevalece sin embargo en estas representaciones una idea presentativa en cuanto a que registra dos personajes, uno normal, el otro anormal, y no una idea descriptiva que deje traslucir el desarrollo de un ritual religioso al que se le pudiera adjudicar la participación un tanto sobrenatural, de seres de poca estatura que intervenian en ceremonias proféticas. Tengo para mí que en los monumentos mencionados los enanos son representativos de seres reales, cuyo registro tuvo propósitos históricos determinables, aunque hasta hoy no podamos conocerlos en toda su amplitud.

En obras de pequeño formato, como son las placas de jade decoradas con relieves, el enano vuelve a aparecer al lado de figuras de indudable jerarquía. En los casos que presento la figura principal voltea en actitud de diálogo hacia su diminuto interlocutor. En la placa del Museo de Historia Natural de Nueva York, el pequeño ser deforme, parado, extiende también el brazo hacia el personaje sentado en elaborado trono. En ambas placas, el atavio de los enanos es también rico. Su situación de prestigio y cercanf́a con los niveles más altos es obvia, el carácter de su rango social es menos claro, a mi juicio, ya que la ausencia de objetos asociados a ellos, como en los casos anteriores, los colocaría, con mayor margen de certeza, como acompañantes formando parte así del séquito de los dignatarios. Sabemos por las fuentes que enanos y jorobados acompañaban a la nobleza azteca en periodos mesoamericanos más tardíos. ${ }^{12}$

En conclusión durante el Clásico Tardío Maya sólo podemos asumir,

12 Satherthwaite, 1961, p. 72. 
por los vestigios artísticos que de los enanos tenemos que, socialmente tuvieron un status alto que los puso en relación directa con la alta aristocracia de la época y presumir que esta relación, de acuerdo con los ejemplos mencionados, estuvo en función del desempeño de cargos específicos de tipo tal vez administrativo, que formaron parte del séquito de los señores con atribuciones jerárquicas que podemos suponer hubiesen sido de carácter mágico-religioso en relación a los augurios 0 vaticinios $\mathrm{y}$ al sacrificio humano o que también pudiesen haber funcionado como bufones o acompañantes de la clase alta en la manera en que lo fueron para la nobleza azteca y en situación semejante a la que tuvieron en las cortes europeas.

Quede, pues, asentado aquí, la especial categoría del enano en aIgunas instancias del arte maya. La sociedad de la época parece haber tenido especial interés en dignificar la congénita anormalidad de estos seres humanos al concederles un rango especial que les dio riqueza en el vestir y frecuentemente colocó su imagen al lado de la de los grandes dignatarios. 


\section{BIBLIOGRAFfa}

Anders, Ferdinand

1965 Das Pantheon der Maya. Akademische Druck-u Verlagsanstalt. Graz/ Austria.

Coe, Michael

1966 The Maya. Ancient Peoples and Places. Thames \& Hudson. London.

Coggins, Clemency

1975 Painting and Drawing Styles a Tikal. Department of Fine Arts. Harvard University. Doctoral Thesis (ms).

Easby K. Elizabeth \& John F. Scott

1970 Before Cortes. Sculpture of Middle America. A centennial exhibition at The Metropolitan Museum of Art. N. York, Sept. 1970-January 1971.

Ekholm F. Gordon

1970 Introducción al catálogo: Ancient Mexico and Central America. The American Museum of Natural History, Nueva York.

Kubler, George

1969 Studies in Classic Maya Iconography. Memoirs of The Connecticut Academy of Arts \& Sciences. Vol. xvin, September, New Haven, Connecticut.

Linne, $\mathbf{S}$.

1943 Humpbacks in Ancient America. Ethnos: 4. The Ethnographical Museum of Sweden, Stockholm.

Mesa Redonda

1942 Mayas y Olmecas. Sociedad Mexicana de Antropología, México.

Merwin, R. E. y G. C. Vaillant

1932 The Ruins of Holmul, Guatemala. Memoirs Peabody Museum. Harvard University. Vol. 3, No. 2, Cambridge.

Miller, H. Jeffrey

1974 Notes on a Stelae Pair, probably from Calakmul, Campeche, Mexico. Primera Mesa Redonda de Palenque. Part I, pp. 149 a 162. The Robert Louis Stevenson School. Pre-Columbian Art Research, Pebble Beach, California.

Parsons, A. Lee

1967 Bilbao, Guatemala. An archaeological study of the Pacific Coast Cotzumalhuapa Regions. Publications in Anthropology 11. Vols. I y II Milwaukee Public Museum. Milwaukee, Wisconsin.

Pendergast, David

1969 The Prehistory of Actun Balam, British Honduras. Royal Ontario Museum. Art and Archaeology Occasional Paper 16. University of Toront Press. 
Proskouriakoff, Tatiana

1960 Historical Implications of a Pattern of Dates at Piedras Negras, Guatemala. American Antiquity, Vol. 25 No 4, University of Utah Press, Salt Lake City.

1964 Portraits of Woman in Maya Art. Essays in Pre-Columbian Art and Archaeology, by Samuel K. Lothrop and others. Harvard University Press. Cambridge, Massachusetts.

Robicsek, Francis

1975 A Study in Maya Art and History. The Mat Symbol. The Museum of the American Indian Heye Foundation. New York.

Ruppert, Karl y John H. Denison Jr.

1943 Archaeological Reconnaissance in Campeche, Quintana Roo and Peten. Carnegie Institution of Washington. Publication. 543. Washington, D. C.

Satherthwaite, Linton

1961 The Carved wooden lintels of Tikal. Appendix: Inscriptions and other dating controls, p. 47 a 78 . Tikal Reports, No 6 . The University Museum, University of Pennsylvania, Philadelphia.

Smith, Robert

1955 Ceramic Sequence at Uaxactun, Guatemala. Tulane University. Middle American Research Institute. Publication No 20. New Orleans.

Thompson, J. Eric

1973 The Painted Capstone at Sacnite, Yucatan and Two Others at Uxmal. Indiana Ibero-Amerikanisches Institut Preubischer Kulturbesity. Berlin.

1970 Maya History and Religion. University of Oklahoma, Press, Norman. 